\title{
Çanakkale Cephesi'nde Türk Ordusunun Menzil Teşkilatı ve Askeri Ulaştırma Hizmetleri
}

\author{
Mustafa ŞAHİN"
}

$\ddot{O} z$

Çanakkale Muharebelerinde Türk tarafinın başarıya ulaşmasındaki önemli faktörlerin başında Menzil teșkilatı ve askeri nakliye (ulaștırma) hizmetleri gelmektedir. Askeri lojistik ihtiyaçları deruhte etmek maksadiyla 25 Mart 1915 sonrasinda 5'inci Ordu Komutanlı̆̆ emrinde 5'inci Menzil Müfettişliği (Kumandanlı̆̆ı) kurulmuştur.

İkmal maddeleri, düșman deniz topçusunun etki sahasindan uzakta cephe gerisindeki depolara nakledilmiş, buradan siperlere kadar ulaştırılması prensibi üzerinde durulmuştur. İstanbul'dan deniz yoluyla ya da demiryolu ile taşınan ikmal maddeleri Biga'da kurulan ambarlarda depolanmıştır. Buradan mavnalar ve küçük deniz vasıtaları ile ikmal maddelerinin taşınmasına öncelik verilmiştir. Suyolunun kesintiye uğraması durumunda ise Menzil Komutanlığınca öküz, deve ve mekkâre kollar ile ikmal maddeleri intikali yapılmııstır.

Anafartalar ve Arıburnu bölgesindeki birliklerin ikmali için Bigalinın kuzeyinde, Seddülbahir bölgesindeki birliklerin ikmali için Soğanlddere bölgesinde Grup Komutanlıkları depoları kurulmuş, buralardan lojistik destek sağlanmıştor.

İkmal maddelerinin nakliyatında "birliğe kadar götürme" usulü tercih edilmiştir. Menzil Komutanlı̆̆ emrindeki nakliye birliklerinin en önemli problemleri; muharebelerin șiddetlendiği dönemlerde istirahat edememe, nakliye hayvanlarının zayıflğ̆l, nakliye motorlu araçlarının piston ve benzeri yedek parçalarının olmayış̧, İngiliz ve Fransız uçaklarının bombalarından verilen zayiatlar olmuştur.

Çanakkale Muharebelerinde, cephenin İstanbul'a yakınlı̆̆l, "Tekâlif-i Harbiye" ile ikmal maddelerinin yerinden temini ve Balkan harpleri gibi diğer

Dr. Per. Yb., Harp Akademileri Komutanlığı Stratejik Araştırmalar Enstitüsü (SAREN) msahin44m@ yahoo.com ve msahin3@harpak.edu.tr 
muharebelerden alınan dersler sebebiyle ikmal maddesi nakliyatında önemli problemler yaşanmamıștır. Birinci Dünya Savaşı içerisinde lojistik sistemin en verimli biçimde işletildiği cephenin Çanakkale cephesi olduğu değerlendirilebilir.

Anahtar Kelimeler: Çanakkale, Lojistik, Menzil, İkmal, Ulaștırma

\title{
At Çanakkale Front Turkish Army Support Unit Organisation and Military Transport Services
}

\begin{abstract}
Command Support Staff Organization and Military Transport Services are among the important factors that lead to the success of Turkish side at Çanakkale Battles. After March 25, 1915 in order to undertake logistics needs, 5th Command Support Staff Inspectorate was established under the command of the 5th Army Command.

Supply substances were transfered to the storage areas behind the front away from the effects of enemy naval artillery, and from there the principle was to deliver them to the trenches. Supply materials transported from İstanbul by sea or by rail were stored in warehouses established in Biga. From Biga, the priority was given to tranfering the materials by means of barges or small sea vehicles. In case of interruption of the waterway, Support command provided the transport of the supply materials by ox, camel and mekkare (rented beasts of burden) convoys.

For the resupply of the troops at Anafartalar and Artburnu area, Group command stores were established at the North of Bigall, fort he resupply of the troops at Seddülbahir area, Group Command stores were establihed and logistics support had been provided.

Take up to the unit procedure was preferred for the transport of supply materials. Most important problems of the units under the command of Command Support Staff: inability to rest in the periods of intensified hostilities, the weakness of the shipping animals, absence of pistons and similar spare parts of motor transport vehicles, and casualities given by British and French bombardment planes.

In the Battle of Çanakkale, no important problem was experienced in the transport of supply materials because of the proximity of the front to Istanbul, providing the supply materials locally by "Tekâlif-i harbiye" (a kind of war tax) and lessons learned from Balkan wars. It can be assesed that In the First World War, logistics system was operated most efficiently at Çanakkale Front.
\end{abstract}

Keywords: Dardanel, Logistics, Support Unit System, Supply, Transportation 


\section{Giriş}

\section{Birinci Dünya Savaşı'nda Merkezi Lojistik Sistem İçinde Menzil Teşkilatı'nın Yeri}

Birinci Dünya Savaşı'nın başında Osmanlı Ordusu'nun -personel ve lojistik bakımından- harbe hazırlık seviyesini en üst düzeye çıkarmak maksadıyla 2 Ağustos 1914'te genel seferberlik ilan edilmiştir ${ }^{1}$. Seferberlik emri Harbiye Nezareti'ne tebliğ edilmiş, aynı zamanda seferberlik müddetince örfi idare ilan olunmuştur. Seferberlik ilanı sonrası Sultan 5'inci Mehmet Reşat tarafından seferliği desteklemek maksadıyla 11 Kasım 1914 tarihinde "Cihad-ı Ekber" ilan edilmiştir. İlan edilen "cihad" gazetelerde yayınlanarak halka ve dünyaya duyurulmuştur².

Seferberlik planlarını hazırlayan Osmanlı Kurmay Subayları, seferberliğin 21 gün, "hatta çoğu durumda 30 ile 45 gün alacağını" düşünmüşlerdir. Oysa şartlar Osmanlı Ordusu'nun seferber olması için hiç de uygun değildir. Yetersiz ulaştırma ağları birliklerin seferber olma hazırlıklarını zorlaştırmıştır. Çanakkale Cephesi'nin silahlı kuvvetler ikmal ihtiyaçlarının çoğu İstanbul ve yöresinden toplanmıştır ${ }^{3}$.

Birinci Dünya Savaşı’nın başında Başkumandanlığa bağlı ve onun koordinesinde yürüyen Erkan-1 Harbiye Umumi Riyaseti, Harbiye Nezareti gibi merkezi teşkilatların içerisinde lojistik teşkilatı şu şekilde yer almıştır: Harbiye Nezareti içerisinde lojistik ve idari faaliyetler; Ordu Dairesi (Ordu ikmal şubeleri), Harbiye Dairesi (Piyade, Süvari, Topçu, Muharebe, Nakliye şubeleri, Askeri fabrikalar), Levazım Dairesi (Yolluk, Maaş, Yiyecek, Giyecek, İnşaat işleri), Muhasebat Dairesi (Hesap işleri), Muamelat-1 Zatiye (Personel Planlama Atama işleri), Hukuk Müşavirliği, Divan-ı Temyiz-i Askeri Riyaseti (Askeri Temyiz Mahkemesi Başkanlığı), Sıhhiye Müfettişliği (Sağlık Daire Başkanlığı), Baytar Müfettişi Umumiliği (Veteriner Dairesi) şubeleri vb. ile yürütülmüştür. Erkan-1 Harbiye Umumi Riyaseti içerisinde ise lojistik ve idari faaliyetler; Menzil Umumi Müfettişliği, Topçu ve Mühimmat şubeleri, Şimendifer Demiryolu Şubesi (demiryolu, ulaştırma), Sıhhiye Müfettişlikleri vb. eliyle yürütülmüştür ${ }^{4}$.

Osmanlı Orduları ile Umumi Karargâh arasında koordinasyon sağlamak maksadıyla 5 Ağustos 1915'de Erkan-ı Harbiye Umumi Riyaseti’ne bağlı Menzil Umu-

1 Seferberlik çağrısı “Osmanlılar Silah Başına!” ilanları ile duyurulmuştur, (Mehmet Beşikçi, Between Voluntarism And Resistance: The Ottoman Mobilization Of Manpower In The First World War, Boğaziçi Üniversitesi, İstanbul, 2009, s. 89 (Yayınmamış Doktora Tezi)); "Silah Başına” çağrıları hala geçerli olarak günümüzde de kullanılmaya devam edilmektedir (Y.N.).

2 Mücahit Özçelik, Türk Basını'nda Osmanlı Devleri’nin I. Dünya Savaşı’na Giriş Süreci, Gazi Üniversitesi Sosyal Bilimler Enstitüsü, Ankara, 2006, s. 46,99-103 (Yayınlanmamış Yüksek Lisans Tezi); Cihad-1 Ekber, 14 Kasım 1914'te Fetva Emini ve Şeyhülislam tarafından yayınlanan tarafından verilen fetvalarla desteklenmiştir, (Ali Fuat Örenç, Yakınçăg Tarihi (1789-1918), Ati Yay., İstanbul, 2012, s. 241).

3 Erdward J. Erickson, Dünya Savaşı Tarihi, I. Dünya Savaşı’nda Osmanlı 1914-1918, Cilt: IV, (Çev.: Sare Levin Atalay), Timaş Yay., İstanbul, 2011, s. 26-27.

4 Birinci Dünya Harbi’nde Türk Harbi V nci Cilt Çanakkale Cephesi Harekâtı 1 nci Kitap (Haziran 1914-25 Nisan 1915), Genelkurmay Başkanlığı, ATASE Yay., Ankara, 1993, s. 255-256. 
mi Müfettişliği kurulmuştur. Menzil Umumi Müfettişliği, Harbiye Nezareti, Erkan-ı Harbiye Umumi Riyaseti gibi merkezi teşkilatların yanı sıra, merkezi teşkilatların lojistik gayretlerini ast birlikler olan ordu komutanlıkları arasında bir nevi köprü görevini üstlenmiştir. Menzil Umumi Müfettişliği kuruluşunda Menzil Umumi Müfettişi Yaveri, Menzil Erkan-1 Harbiye Reisi, Menzil Erkan-1 Harbiye Reisi muavinleri, Umumi Levazım Hizmetleri Uzmanları, Silah ve Mühimmat Şubesi, Muhabere Şubesi, Sıhhiye Hizmetleri Şubesi ve Evrak Kalemi yer almıştır. Yine Menzil Umumi Müfettişliğine bağlı ordular bölgesinde Ordu Menzil Müfettişlikleri kurulmuştur. Ordu Menzil Müfettişliklerine bağlı olarak Menzil Bölge Müfettişlikleri, Menzil Hat Komutanlıkları, Birinci ve İkinci Sınıf Menzil Nokta Komutanlıkları, Menzil İstasyon Komutanlıkları, Konaklama Komutanlıkları, Menzil Yiyecek ve Teçhizat Ambarları, İnsan ve Hayvan Hastaneleri, kolları hizmet görmüşlerdir. Yine bu hizmetlerin bir kısmı ağırlığına göre Kolordu ve Tümen komutanlıklarınca yerine getirilmiștir ${ }^{5}$. Bu dönemde Menzil Umumi Müfettişliği görevi, Kurmay Yarbay Nihat (Korg. Anılmış) Bey tarafından deruhte edilmiştir 6 .

Menzil Bölge Müfettişlikleri kuruluşu ve teşkilatları Menzil Umumi Müfettişliği benzeri olmakla birlikte personel sayıca azaltılmıştır. Menzil Hat Komutanlıkları kuruluşunda; Muhafız Komutanlığı, Hizmet ve Amele Kıt'ası, Tamir Onarım Kolu, Yol İnşa Kıt'ası, İaşe Merkezi, Er Misafirhanesi, Erzak ve Yem Deposu, Cephane Deposu, Hayvan Deposu, Sevk Memurluğu ve Sağlık Hizmeti unsurlarından teşekkül ettirilmiştir. Menzil Bölge Müfettişlikleri emrinde büyüklüklerine göre birkaç Nokta ve Konak Komutanlığı kurulmuştur ${ }^{7}$.

\section{5'inci Ordu'nun Kurulması Öncesi Çanakkale Cephesi'nde Menzil Teşkilatı ve Askeri Nakliye Hizmetleri}

Birinci Dünya Savaşı'nda başlangıçta, Çanakkale Cephesi’nde Ordu teşkiline geçilmeden önce harekât alanının lojistik ihtiyaçlarından sorumlu birlik; Çanakkale Müstahkem Mevki Komutanlığı olmuştur. 5’inci Ordu Komutanlığının kurulduğu 25 Mart 1915’e kadar 9'uncu Tümen Komutanlığı da Müstahkem Mevki Komutanlığına bağlı olarak muharebe etmiştir. 18 Mart 1915’de Müttefiklerin boğazı zorlama

5 Birinci Dünya Harbi’nde Türk Harbi Vnci Cilt Çanakkale Cephesi Harekâtı 1 nci Kitap, s. 255.

6 Yarbay Nihat (Anılmış) Bey, 1878'de Filibe'de dünyaya gelmiştir. 1896'da Teğmen, 1897'de Üsteğmen, 1900'de Yüzbaşı, 1907'de Binbaşı, 1912'de Yarbay, 1914'te Albay, 1915'de Tümgeneral, 1928'de Korgeneral rütbelerini almıştır. 3 Ağustos 1914’te aldığı Menzil Umumi Müfettişliği görevini 21 Mart 1915’e kadar sürdürmüștür. Balkan Savașı, Birinci Dünya Savașı ve Kurtuluş Savaşı'nda önemli görevler almıştır, (Hülya Toker, Çanakkale Muharebelerine Katılan Komutanların Biyografileri (Belge ve Fotoğraflarla), Genelkurmay Askerî Tarih ve Stratejik Etüt (ATASE) Daire Başkanlığı Yay., Ankara, 2014, s. 479-480).

7 Cezmi Tezcan, Tekâlif-i Harbiye ve Tekâlif-i Milliye Örneklerinde Savaş Dönemleri Mâli Politikaları, Ankara Üniversitesi Türk İnkılâp Tarihi Enstitüsü, Ankara, 2005, s. 75-76 (Yayımlanmamış Doktora Tezi). 
taarruzları sırasında yapılan muharebe sonrasında Çanakkale Müstahkem Mevki Komutanlığı 115 şehit ve yaralı kayıp vermiştir ${ }^{8}$. Çanakkale Müstahkem Mevki Komutanlığı, bu dönemde (Kasım 1914'de 1 hafta hariç), 9'uncu Piyade Tümeni de emir ve kuruluşunda olduğu halde doğrudan Başkomutanlığa bağlı olarak harekât ve lojistik görevleri birlikte icra etmiştir ${ }^{9}$. Çanakkale Müstahkem Mevki Komutanlığı görevini bu dönemde Cevat Paşa (Org. Çobanlı) tarafından deruhte edilmiştir ${ }^{10}$.

Buna göre, Çanakkale Müstahkem Mevki Komutanlığı ve 9'uncu Tümen Menzil teşkilatına bağlı birlikleri şöyle teşkilatlanmıştır: ${ }^{11}$

\begin{tabular}{|c|c|}
\hline Menzil Teşkilatı Unsurunun Adı & Yeri \\
\hline 5’inci Ağır Erzak Kolu & \multirow{3}{*}{ Çanakkale'de } \\
\hline 5’inci Yinelemeli (develi) Ağır Erzak Kolu & \\
\hline 6'ncıYinelemeli Ağır Erzak Kolu & \\
\hline 7'nci Piyade (develi) Cephane Kolu & Okçular'da \\
\hline 8'inci Piyade (develi) Cephane Kolu & \multirow{2}{*}{ Çanakkale'de } \\
\hline 5’inci Dağ Topçu Cephane Kolu & \\
\hline 6’ncı Dağ Topçu Cephane Kolu & Yağcılar'da \\
\hline 7'nci Sahra Topçu Cephane Kolu & Kepez'de \\
\hline 8'inci Sahra Topçu Cephane Kolu & \multirow{2}{*}{ Çanakkale'de } \\
\hline 9'uncu Sahra Topçu Cephane Kolu & \\
\hline 6'ncı Seyyar Hastane & Kalvert Çiftliğinde \\
\hline 9'uncu Tümen Bandosu & Kalvert Çiftliğinde \\
\hline Ekmekçi Müfrezesi & Eceabat'ta \\
\hline Esas Depo Taburu & Çanakkale'de \\
\hline 3’üncü Hayvan Deposu & Çanakkale'de \\
\hline
\end{tabular}

19’uncu Tümen Komutanlığı Menzil teşkilatına bağlı birlikleri ise şöyle teşkilatlanmıștır: ${ }^{12}$

8 Ruşen Eşref ve Hamdullah Suphi vd., Çanakkale, Savaşanlar Anlatıyor, Örgün Yay., İstanbul, 2006, s. 385.

9 Birinci Dünya Harbi'nde Türk Harbi V nci Cilt Çanakkale Cephesi Harekâtı 1 nci Kitap, s. 256.

10 İsmet Görgülü, On Ylllık Harbin Kadrosu (1912-1922), TTK Yay., Ankara, 1993, s. 62.

11 Birinci Dünya Savaşı’nda Çanakkale Cephesi Harekâtı (Haziran 1914-25 Nisan 1915), V. Cilt 1. Kitap, Genelkurmay Personel Başkanlığı ATASE Daire Başkanlığı Yay., Ankara, 2012, s. 229.

12 Birinci Dünya Savaşı’nda Çanakkale Cephesi Harekâtı (Haziran 1914-25 Nisan 1915), V. Cilt 1. Kitap, s. 230. 


\begin{tabular}{|l|c|}
\hline Menzil Teşkilatı Unsurunun Adı & Yeri \\
\hline 4'üncü Hafif Erzak Kolu & \multirow{2}{*}{ Eceabat'ta } \\
\hline 4'üncü Ağır Erzak Kolu & \\
\hline Ekmekçi Takımı & \\
\hline 1'inci Piyade Cephane Kolu & Bigalı köyünde \\
\hline 2'nci Piyade Cephane Kolu & \multirow{2}{*}{ Eceabat'ta } \\
\hline 3'üncü Dağ Topçu Cephane Kolu & \\
\hline Sıhhiye Bölüğü & Gelibolu'da \\
\hline 5'inci Seyyar Hastane & \\
\hline 19'uncu Tümen Bandosu &
\end{tabular}

11'inci Tümen Komutanlığı Menzil teşkilatına bağlı birlikleri ise şöyle teşkilatlanmıştır: ${ }^{13}$

\begin{tabular}{|c|c|}
\hline Menzil Teşkilatı Unsurunun Adı & Yeri \\
\hline 6’ncı Hafif Erzak Kolu & \multirow{7}{*}{ Ezine'de } \\
\hline 4'üncü Ağır Erzak Kolu & \\
\hline 5’inci Sahra Topçu Cephane Kolu & \\
\hline 7’nci Sahra Topçu Cephane Kolu & \\
\hline Ekmekçi Takımı & \\
\hline Sihhiye Bölüğü & \\
\hline Seyyar Hastane & \\
\hline 5 'inci Hafif Erzak Kolu & \multirow{5}{*}{ Bayramiç'te } \\
\hline 8’inci Ağır Erzak Kolu & \\
\hline 3’üncü Piyade Cephane Kolu & \\
\hline 5'inci Piyade Cephane Kolu & \\
\hline 2’nci Dağ Topçu Cephane Kolu & \\
\hline
\end{tabular}

2'nci ve 3'üncü Kolordu Komutanlıkları Menzil teşkilatına bağlı birlikleri ise şöyle teşkilatlanmıştır: ${ }^{14}$

13 Birinci Dünya Savaşı’nda Çanakkale Cephesi Harekâtı (Haziran 1914-25 Nisan 1915), V. Cilt 1. Kitap, s. 230.

14 Birinci Dünya Harbi’nde Türk Harbi V nci Cilt Çanakkale Cephesi Harekâtı 1 nci Kitap, s. 231. 


\begin{tabular}{|c|c|}
\hline Menzil Teșkilatı Unsurunun Adı & Yeri \\
\hline 2'nci Hafif Erzak Kolu & \multirow{4}{*}{ Gelibolu'da } \\
\hline 3’üncü Hafif Erzak Kolu & \\
\hline 2’nci Ağır Erzak Kolu & \\
\hline 3’üncü Ağır Erzak Kolu & \\
\hline 1'inci Hafif Erzak Kolu & Markoplu'da \\
\hline 1'inci Ağır Erzak Kolu & Bayırköy'de \\
\hline 1'inci Cephane Taburu Karargâhı & Galata'da \\
\hline 3’üncü Piyade Cephane Kolu & Kavaklı'da \\
\hline 5'inci Piyade Cephane Kolu & Burgaz'da \\
\hline \multirow[b]{2}{*}{ 1'inci Sahra Topçu Cephane Kolu } & Muhipbey \\
\hline & Çiftliğinde \\
\hline 2'nci Sahra Topçu Cephane Kolu & Bakırköy'de \\
\hline 3’üncü Sahra Topçu Cephane Kolu & Burgaz'da \\
\hline 4’üncü Sahra Topçu Cephane Kolu & \multirow{2}{*}{ Tayfur'da } \\
\hline 1'inci Dağ Topçu Cephane Kolu & \\
\hline 2'nci Dağ Topçu Cephane Kolu & Galata'da \\
\hline Seyyar Hastane & Gelibolu'da \\
\hline Sıhhiye Bölüğü & Galata'da \\
\hline
\end{tabular}

Çanakkale cephesinde ikmalde yut içi ve yurt dışı tedarik sistemi uygulanmıştır. Almanya ve Avusturya-Macaristan ile müttefiklimiz olması sebebi ile savaş dışındaki diğer bazı ülkelerden ise tarafsız olması sebebiyle dış tedarik yapılmıştır. Çanakkale Cephesinde iç kaynak olarak yerinden tedarik sistemi ile harekât bölgesine yakın vilayetlerin kaynaklarından öncelikle istifade edilmiştir. İç kaynak bölgesi, başta İstanbul olmak üzere harekâtı kapsaması yönüyle Çanakkale bölgesi olmuştur. Burada genellikle ikmal maddeleri satın alıma ve borçlanma suretiyle kolordu ve tümenlerin harekât ve menzil hizmet alanlarından sağlanmıștır. Çanakkale cephesinde 5 'inci Ordu Komutanlığının kurulduğu 25 Mart 1915’e kadar uygulanan menzil teşkilatının konuş yerleri $E k-1$ 'de sunulmuștur ${ }^{15}$.

Bu dönemde icra edilen Askeri nakliye hizmetlerine gelince; Çanakkale bölgesi için başlıca ulaşım yolu deniz yolu olarak tercih edilmiştir. Ana depo, fabrika ve öteki tesisler, İstanbul ve Marmara Denizi çevresinde bulunmaktadır. Çanakkale'nin Bandırma'ya olan mesafesi 96 mil (178 km), Tekirdağ’a olan mesafesi 74 mil (137 km)'dir. Çanakkale'nin İstanbul'a olan uzaklığı 135 mil (250 km)'dir. Bu mesafeyi gemiler, 10-12 saatte alabilmiştir. Büyük ölçüde ağır malzemenin taşınması için deniz yolu kullanılmıştır. Deniz yolu, düşman denizaltı gemilerine karşı güven altında bu-

$\overline{15}$ Birinci Dünya Harbi’nde Türk Harbi V nci Cilt Çanakkale Cephesi Harekâtı 1 nci Kitap, s. Kroki:18. 
lundurulmasına bağlı olarak kullanılmıştır. Öte yandan karayolu ulaştırması olarak Çanakkale-Umurbey-Biga-Bandırma yolu, menzil yolu -ana ikmal yolu- olarak kullanılmıştır. Uzunköprü yolu ikinci bir menzil yolu -ikinci ikmal yolu- olarak kullanılmıştır. Oldukça yetersiz olan bu yol, Saros Körfezi'ne açıldığından ve uzun olduğundan sınırlı ölçüde ulaşım sağlanabilmiştir ${ }^{16}$.

Çanakkale Cephesinde karayolu askeri ulaştırmasında düşmanın gözünden ve ateşinden uzak olan iç karayolu kullanılmıştır. Üstün düşman ateş kudreti sebebiyle yarımadanın iç ve orta kısımları karayolu askeri nakliyatı için tercih edilmiştir. Suyolu ve karayolu iç kesilmede ise kısmen demiryolu ulaştırmasının kullanıldığı Çanakkale cephesinde genel ikmal prensibi olarak "birliğe kadar götürme” usulü benimsenmiştir. Ancak bazı ikmal maddeleri için "ikmal noktası taşıma usulü” uygulanmıştır.

Harbin başlarında Harbiye Nezareti; Çanakkale Cephesini desteklemek maksadıyla "birliklerden ellerindeki otomobil ve avadanlık mevcutlarını Levazım Daire Başkanlığına bildirmeleri emredilmiştir”. Tespit edilen araçlar, Nakliye ve Muhabere Umumi Müfettişliği emrine verilerek İstanbul'da bir Araç parkı kurulmuştur. Söz konusu araçlar; şoförleri, muavinleri ve yedek parçaları ile birliklerden toplanarak Çanakkale'ye malzeme ve personel sevkiyatında kullanılmıştır. Ayrıca arızalanan araçlar için bir tamirhane açılmış, yakıt taşımak için bir kol, araç kurtarma ve onarım için bir kol olmak üzere iki kol kurulmuştur ${ }^{17}$.

Askeri nakliye kolları, genel olarak yiyecek ve cephane kolları olarak ikiye ayrılmışlarsa da taşıma işlerinde zorunlu durumlarda biri ötekinin yerine kullanıldığı gibi kollara başka taşıma görevi de verilmiştir. Genel olarak taşıma işlerinde kullanılacak tek taşıtlar için taşıma faktörü şöyle olmuştur:: ${ }^{18}$

\begin{tabular}{|l|l|}
\hline Karayolu Nakliye Vasıtası & Taşıma Kapasitesi \\
\hline Öküz ve manda arabası & $600 \mathrm{~kg}$. \\
\hline Çift atlı araba & $400 \mathrm{~kg}$. \\
\hline Kağnı & $150 \mathrm{~kg}$. \\
\hline Deve & $200 \mathrm{~kg}$. \\
\hline Yük hayvanları & $80 \mathrm{~kg}$. \\
\hline
\end{tabular}

16 Birinci Dünya Savaşı’nda Çanakkale Cephesi Harekâtı (Haziran 1914-25 Nisan 1915), V. Cilt 1. Kitap, s. 271.

17 Özgür Keskin, Çanakkale Muharebeleri’nde Türk Ordusunun Lojistik Faaliyetleri, Kara Harp Okulu Savunma Bilimleri Enstitüsü, Ankara, 2007, s. 87 (Yayınlanmamış Yüksek Lisans Tezi).

18 Birinci Dünya Savaşı'nda Çanakkale Cephesi Harekâtı (Haziran 1914-25 Nisan 1915), V. Cilt 1. Kitap, s. 241. 


\section{5'inci Ordu'nun Kurulması (25 Mart 1915) Sonrası Çanakkale Cephesi'nde Menzil Teșkilatı ve Askeri Nakliye Hizmetleri}

Osmanlı Başkomutanlık Vekâleti, Mart ayında yapılan muharebeler sonrası Çanakkale Cephesinde yeni düzenlemeler yapma gereği duymuştur. Çanakkale Cephesinde emir-komuta birliği sağlamak maksadıyla ordu komutanlığı kuruluşuna geçilmiştir. Bu amaçla; 24 Mart 1915'te yazılan bir emirle Alman Mareşal Otto Liman von Sanders ${ }^{19}$ komutasında 5 'inci Ordu Komutanlığı kurulmuştur. Ordu Karargâhı Gelibolu'da konuşlanmıștır. 5 'inci Ordu Komutanlığı bağlı birlikleri: 3’üncü Kolordu: Komutanı Esat Paşa ${ }^{20}$, birlikleri 7'nci, 9'uncu 19'uncu Tümenler, Mürettep Kolordu (sonradan 15'inci Kolordu): Komutanı Alman Weber Paşa ${ }^{21}$, birlikleri 11'inci, 3'üncü Tümenler, 5'inci Tümen: Komutanı Albay Hasan Basri Bey ${ }^{22}$, Bağımsız Süvari Tugayı: Komutanı Yarbay Hamdi Bey, olacak șekilde teșkil edilmiştir ${ }^{23}$. O zamana kadar Çanakkale Cephesinin Menzil sistemini büyük ölçüde deruhte eden Müstahkem Mevki Komutanlığına ise sürekli olarak 5 'inci Ordu Komutanlığı ile irtibatta bulunarak "işbirliği yapması" emri verilmiștir ${ }^{24}$.

5 'inci Ordu Komutanlığı bağlllarından 3’üncü Kolordunun birlikleri Gelibolu yarımadasında (9'uncu Tümen Eceabat'a geçerek yeniden kolordu kuruluşuna girmiştir.) 15’inci Kolordu birlikleri Çanakkale güneyinde Şarköy’ün batısında ve Yeniköy dolayında, 5 ’inci Tümen birlikleri Keşan’ın güneyinde, Bağımsız Süvari Tugayı Karapınar ve dolayında konușlanmıștır25 ${ }^{25}$ 'inci Ordu Komutanlığı kurulușu Ek-2'de sunulmuștur ${ }^{26}$.

5 'inci Ordu Komutanlığının Menzil teşkilatına gelince; Çanakkale Cephesinin lojistik ihtiyaçlarını deruhte etmek maksadıyla 27 Mart 1915'de karargâhı Gelibolu'da

19 Alman Mareșal Liman von Sanders atamayı müteakip 26 Mart 1915’te Gelibolu'ya gelerek göreve başlamış, aynı gün -cephe hattını görmek üzere- Bolayır’a hareket emiştir, (Zekeriya Türkmen, Çanakkale 1915 Türk Ordusunun Kara ve Hava Harekatt, Berikan Yay., Ankara, 2010, s.38).

20 Esat (Bülkat) Pașa, Çanakkale Cephesi'nde 3'üncü Kolordu Komutanlığını 06 Ocak 1914'ten 12 Ekim 1915 tarihine kadar sürdürmüş daha sonra bu görevi Ali Rıza (Sedes) Paşa'ya devretmiş, Ali Rıza Paşa bu görevi 11 Kasım 1915'den 1 Mart 1917'ye kadar sürdürmüştür, (Toker, Çanakkale Muharebelerine Katılan Komutanların ..., s. 170-171. EK-B).

21 Weber Paşa Çanakkale Cephesinde; İkinci Kirte (6 Mayıs - 8 Mayıs 1915) 9-24 Mayıs Muharebeleri, Üçüncü Kirte (4-6 Haziran 1915),1'inci Kerevizdere (21-22 Haziran 1915), Zığındere (28 Haziran-3 Temmuz 1915), 5 Temmuz Zığındere Muharebelerinde görev almıștır, (Görgülü, On Yıllık Harbin Kadrosu..., s. 69, 70, 72, 74, 76).

22 Birinci Dünya Savaşı'nda Çanakkale Cephesi Harekâtı (Haziran 1914-25 Nisan 1915), V. Cilt 1. Kitap, s. Ek-1.

23 Çanakkale Cephesi’nde Haziran 1915 sonrası 5 'inci Or.K.lığına bağlı Grup teşkilatına geçilmiştir.

24 Birinci Dünya Savaşında Çanakkale Cephesi Harekâtı (Haziran 1914-25 Nisan 1915), V. Cilt 1. Kitap, s. 193-194.

25 Birinci Dünya Savaşı’nda Çanakkale Cephesi Harekâtı (Haziran 1914-25 Nisan 1915), V. Cilt 1. Kitap, s. 203.

26 Birinci Dünya Harbi'nde Türk Harbi V nci Cilt Çanakkale Cephesi Harekâtı 1 nci Kitap, s. Kuruluș:12. 
olacak şekilde 5’inci Ordu Menzil Müfettişliği kurulmuştur. Müfettişliğin kuruluşu 27 Mart 1915'deki $E k$-3'de $e^{27}$, daha sonra Eylül 1915'de oluşan kuruluşu ise Ek-4'de ${ }^{28}$ sunulmuştur. Daha sonra 5 'inci Ordu Komutanlığının ileri hareketi sebebiyle Ordu Menzil Müfettişliği de 9 Mayıs 1915'te karargâhının ileri kademesiyle Akbaş'a, geri kademesiyle de Lâpseki'ye intikal etmiştir ${ }^{29}$. Ordu Menzil Müfettişliğinin ileri hareketi safhasında Gelibolu kaza merkezinde bir menzil nokta komutanlığı bırakılmış$\operatorname{tir}^{30}$.

1915 Ağustos ayının sonunda 5’inci Ordu Menzil Müfettişliği'nin “istenilen hizmeti verememesi sebebiyle” genel merkezinin Akbaş olması kaydıyla, 5 'inci Ordu'da Avrupa, Asya ve Bahrî işlerin ayrı ayrı ifa edileceği üç müstakil menzil müfettişliği kurulmuştur. ${ }^{31}$

Çanakkale Cephesinde ordunun yiyecek ve nakliye vasıtalarının ihtiyacı, Menzil Müfettişliklerinin illerdeki temsilcileri aracılığıyla ve tekâlifi harbiye ${ }^{32}$ usulüyle sağlanmıştır. Ayrıca ordu hizmetlerine uygun vasıftaki nakliye vasıtaları ile gelenlere, kurulacak menzil kollarında görev verileceği duyurulmuştur. Başlangıçta 1'inci ve 5 'inci Orduların menzil komutanlıkları arasındaki ara hattı, Gelibolu batısındaki Galata Köyü-Saz Limanı hattı olmuştur. Bölgenin dar ve kaynaklarının çok kısır olmasından dolayı menzil bölgeleri değiştirilmiş 1'inci ve 5’inci Orduların menzil ara hattı, Çatalca mevziinin batısındaki Podima-Silivri hattı (1'inci Menzil Bölgesine dâhil) olarak tespit edilmiştir. Bu yeni düzenlemeye göre 5'inci Ordu Menzil Müfettişliğinin sınırları, Podima-Silivri hattının batısında kalan Trakya bölgesiyle Anadolu yakasında Biga (dâhil)-Edremit (hariç) hattı olarak belirlenmiştir. Böylece 5 ’inci Ordu

27 Türk Silahlı Kuvvetleri Tarihi Osmanlı Devri Birinci Dünya Harbi’nde Türk Harbi V nci Cilt 3 ncü Kitap Çanakkale Cephesi Harekâtı (Haziran 1915-Ocak 1916), Genelkurmay Başkanlığı ATASE Yay., Ankara, 1980, s. Kuruluş:15.

28 Türk Silahlı Kuvvetleri Tarihi Osmanlı Devri Birinci Dünya Harbi’nde Türk Harbi V nci Cilt 3 ncü Kitap Çanakkale Cephesi Harekâtı (Haziran 1915-Ocak 1916), s. Kuruluş:16.

29 Birinci Dünya Savaşı'nda Çanakkale Cephesi Harekâtı (Haziran 1914-25 Nisan 1915), V. Cilt 1. Kitap, 2012, s. 203.

30 Birinci Dünya Savaşı’nda Çanakkale Cephesi (Amfibi Harekat), (V. Cilt, II. Kitap), Genelkurmay Personel Başkanlığı ATASE Daire Başkanlığı Yay., Ankara, 2012, s. 231.

31 Lokman Erdemir, Çanakkale Savaşı Siyasi Askeri ve Sosyal Yönleri, Gökkubbe Yay., İstanbul, 2009, s. 236.

32 Harp vergisi, Tekâlif-i Harbiye Kanunu ile savaş sebebiyle ortaya çıkan olağanüstü giderleri karşılamak maksadıyla alınan, hem bazı vergi oranlarında artışları, hem harp sırasında ihtiyaç duyulan araç-gerece, erzaka, taşıma için hayvanata ve mühimmata, bedeli kısmen veya tamamen ileride ödenmek üzere el konulmasını, hem de çeşitli maaş, ücret ve aylıklardan kesintileri içeren bir vergi olarak uygulanmıştır. Karşılıkları sonra ödenmek üzere alınan mallar toplanılırken, bu toplama işlemi Tekâlif-i Harbiye komisyonlarının yerel rayice göre her mal için tespit ettikleri fiyatların bulunduğu fiyat cetveline dayanılarak, mazbata düzenlenip yapılmıştır. Tekâlif-i Harbiye'yi uygulamak maksadiyla 30 Ocak 1912, 18 Ağustos 1912 ve 27 Temmuz 1914'te olmak üzere müteaddit defalar kanunlar çıkarılmıştır. Harp yükümlülüklerini uygulamak maksadıyla da Tekâlif-i Harbiye komisyonları kurulmuştur, (Tezcan, Tekâlif-i Harbiye ve Tekâlif-i Milliye Örneklerinde..., s. 66-73); Söz konusu Tekâlif-i Harbiye uygulaması Milli Mücadele sırasında Başkomutan Mustafa Kemal Paşa tarafından da Tekâlif-i Milliye adıyla uygulanmıştır. 
menzil sınırları, yurdun en verimli ve olanakları en zengin olan Trakya bölgesiyle Marmara havzasının büyük bir kısmını içine almıștır. Böylece lojistik kaynaklar artırılarak harbin neticesine olumlu katkı sağlanmıştır. Ayrıca deniz yollarıyla, o dönemde Türkiye'nin endüstri merkezi olan İstanbul, İzmit, Mudanya ve Bandırma'yla bağlanmış, bu vilayet, sancak ve kazalara ulaşan demiryolu şebekesi, Çanakkale harekât alanının memleket içiyle olan bağlantısını tamamlamıştır. Marmara Denizi üzerindeki deniz ulaştırmasının emniyet altına alınması ve iskelelerle liman kapasitelerinin artırılması cihetine gidilmiş; İzmit-Haydarpaşa demir yolu kısmında, ikmal maddelerinin yükleme-boşaltma hizmetleriyle depolanma imkânlarının artırılması üzerinde durulmuştur. Başkentten harekât alanına ikmal maddelerini taşımak maksadıyla Demiryolu ulaştırması tercih edilmiş, ana ikmal yolu olarak İstanbul-Uzunköprü demiryolu kullanılmıștır³ .

Harbin başlangıcında Çanakkale bölgesindeki birliklerin tüm lojistik maddelerinin günlük ihtiyacı, ortalama olarak, sadece 150 ton olmasına rağmen harbin sıcaklığının arttığı dönemlerde yapılan takviyelerle, 18 Mart 1915 tarihinde Çanakkale harekât alanında bulunan Türk birliklerinin kuvvesi; Müstahkem Mevki sınırları içinde 50.000, Çanakkale harekât alanı içinde ise 95.000 kişiyi bulmuştur. Çanakkale Cephesi'nin takviye edilmesi üzerine 5 'inci Ordunun personel mevcudu, önce 137.599'a; hayvan mevcudu da 24.734'e çıkmış, bu mevcut, Çanakkale Muharebeleri'nin sonlarına doğru 28 Temmuz 1915 tarihinde, 250.823 erle 69.078 hayvana ulaşmıştır ${ }^{34}$. Bu durum karşısında 5 'inci Ordu Menzil teşkilatı daha da genişletilmiştir. 5 'inci Ordunun bu seviyeye ulaşması sonucunda bazı müteahhitler Gayr-i Müslimlerden oluşmaya başlamıştır. Bu durum Başkumandanlığa yazı ile sorulmuş; verilen cevapta "Gayr-i Müslim müteahhitlerin yerinde bırakılması", mümkün ise Müslüman müteahhitlerden gıda maddelerinin tedarik edilmesi, cevabı verilmiştii ${ }^{35}$. Öte yandan genişleyen kadroyu desteklemek maksadıyla "Beşinci Menzil Müfettişliği vesikasına sahip olmayan tacirlerin ordu mıntıkası dâhilinde mevad ve iașe mubayaalarının yasaklanmasına" dair kararlar verilmiştiri3. . Yine "Beşinci Ordu Menzil Müfettişliği vesikası olmayan taburların ordu mıntıkası dâhilinde iașe mübayaa etmeleri” de yasaklanmıștır ${ }^{37}$.

33 Muhammet Erat, "Çanakkale Muharebelerinde Türk Ordusunun İaşe Problemi”, Çanakkale Araştırmaları Türk Yılllğı̆, Çanakkale Onsekiz Mart Üniversitesi Atatürk ve Çanakkale Savaşları Araştırma Merkezi Yay., Sayı: 1, (Mart 2003), 114-133, s. 126-127.

34 Birinci Dünya Savaşı'nda Çanakkale Cephesi Harekâtı (04 Haziran 1915-09 Ocak 1916), V. Cilt III. Kitap, Genelkurmay Personel Başkanlığı ATASE Daire Başkanlığı Yay., Ankara, 2012, s. 483-484.

35 BOA,DH.EUM.,3.Şube, (Dahiliye Nezareti Emniyet-i Umumiye 3.Şube Müdüriyeti), 2/16, 02/M /1335 (Hicrî).

36 BOA, DH.ŞFR., (Dahiliye Nezareti Şifre Kalemi), 558/11, 28/Ha/1333.

37 BOA, İ.UM (Dahiliye Nezareti İdare-i Umumiye), 45/73, 13/N /1335 (Hicrî). 
5 'inci Ordu bölgesindeki Menzil Teşkilatı konuş yerleri $E k-5^{\prime} d e^{38}$ sunulmuştur.

5 'inci Ordu Menzil Müfettişliğinin menzil sahasındaki hatları şöyle belirlenmiştir: ${ }^{39}$

1. Hat: Uzunköprü - Keşan - Gelibolu

2. Hat: Biga - Lâpseki - Çanakkale

3. Hat: Balıkesir - Ezine - Çanakkale

5 'inci Ordu Menzil Müfettişliğinin emrinde bulunan unsurlar şöyle belirlenmiştir: ${ }^{40}$

Menzil Jandarma, Süvari, Piyade ve Muhafız takımları

Telgraf müfrezesi

Sahra Postası Bölüğü

Sahra Jandarması

Menzil Nokta Komutanlıkları:

Uzunköprü, Keşan, Gelibolu, Bayırköy, Ilgardere, Akbaş, Biga Karabiga, Malular, Lapseki, Burgaz ve Çanakkale Nokta Komutanlıkları.

Menzil İskele Komutanlıkları:

Çardak, Gelibolu, Ilgardere, Akbaş, Kilya, Karabiga, Lâpseki, Burgaz (BergazUmurbey) Çanakkale.

Menzil Çayhaneler:

Gülecik, Bayırköy, Yerlisu, Karapınar.

Menzil Ekmekçi Takımları:

Burgaz ve Gelibolu.

Menzil İdari Teşkillerden Erzak Ambarları:

Akbaş, Malular, Uzunköprü, Keşan, Ilgardere, Biga, Karabiga, Gelibolu, Lâpseki, Burgaz, Işıklar.

Mekkâreli Katarlar (tümenlerden geçer):

11'inci Tümen 39 ton, 13'üncü Tümen 32 ton, 10Uncu Tümen 37 ton, 8'inci Tümen 23 ton, 4'üncü Tümen 24 ton, 1'inci Tümen 14 ton.

38 Türk Silahlı Kuvvetleri Tarihi Osmanl Devri Birinci Dünya Harbi’nde Türk Harbi V nci Cilt 3 ncü Kitap Çanakkale Cephesi Harekâtı (Haziran 1915-Ocak 1916), s. Kroki: 60.

39 Türk Silahlı Kuvvetleri Tarihi Osmanlı Devri Birinci Dünya Harbi’nde Türk Harbi V nci Cilt 3 ncü Kitap Çanakkale Cephesi Harekâtı (Haziran 1915-Ocak 1916), s. 524; İrfan Arat, Çanakkale Savaşı'nın Lojistik Desteğinin İncelenmesi ve Savașın sonucuna Etkilerinin Değerlendirilmesi, Harp Akademileri Komutanlı̆̆ı, İstanbul, 2008, s. 4-30 (Kara Harp Akademisi Öğrenci Subay Tezi).

40 Türk Silahlı Kuvvetleri Tarihi Osmanl Devri Birinci Dünya Harbi’nde Türk Harbi V nci Cilt 3 ncü Kitap Çanakkale Cephesi Harekâtı (Haziran 1915-Ocak 1916), s. 525-526. 
Menzil Erzak Nakliye Katarları:

12'nci Tümen Keșan 82 ton, 11'inci Tümen Uzunköprü 118 ton, 10'uncu Tümen Uzunköprü 43 ton, 8 'inci Tümen Uzunköprü 89 ton, 7’inci Tümen Keşan 88 ton, 6’ıncı Tümen Keşan 103 ton, 5’inci Tümen Biga 103 ton, 4'üncü Tümen Biga 115 ton, 3’üncü Tümen Işıklar 83 ton, 1’inci Tümen Uzunköprü 112 ton.

Cephane ve Park teşkilleri:

Burgaz Cephane Deposu, Gelibolu Cephane Deposu, Ilgardere Cephane Deposu, Akbaş İstihkâm Deposu, Akbaş Cephane Deposu, 39'uncu Tümen Akbaş 39 tonluk cephane katarı, 2'inci Tümen Keşan 98 tonluk katar.

Amele ve Hamal kitaları:

Akbaşta 2 adet Hamal Taburu Uzunköprü, Keșan ve Gelibolu Hamal Bölükleri.

Amele Taburları:

Yalova 2 tabur, Biga 2 tabur, Burgaz 1 tabur, Ilgardere, Çorlu 1 tabur, Biga İnşaat bölüğü, Lâpseki araba imalathanesi, Ilgardere köprücü takımı.

Menzil Sağlık tesisleri, Harp Hastaneleri:

Dümerek 300 yataklı 5’inci Harp Hastanesi, Şarköy 200 yataklı 6'ncı Harp Hastanesi, Lâpseki 1100 yataklı 2'inci Harp Hastanesi, Çardak 850 yatak lı 1'inci Harp Hastanesi.

Menzil Hastaneleri:

Keşan 180 yatak, Erdek 600 yatak, Karabiga 150 yatak, Mürefte 400 yatak, Lâpseki 500 yatak 4'üncü Menzil Hastanesi, Bayırköy 500 yatak 2'nci Menzil Hastanesi, Bayırköy 500 yatak 3'üncü Menzil Hastanesi, Dimetoka 650 yatak 3'üncü Menzil Hastanesi, Biga 1000 yatak 2'nci Menzil Hastanesi, Biga 850 yatak 1'inci Menzil Hastanesi.

Merkez Hastaneleri:

850 yataklı Tekirdağ Merkez Hastanesi, 1600 yataklı Gelibolu Merkez Hastanesi.

Seyyar Hastaneler:

Tekirdağ 300 yataklı Kızılay Hastanesi, Eriklice 2000 yataklı 8'inci Tümen Seyyar Hastanesi, Burgaz 10'uncu Tümen 1500 yataklı Seyyar Hastanesi, Ilgardere 600 yataklı 12'nci Tümen Seyyar Hastane, Galata 600 yataklı Salgın Hastanesi, Biga Hasta Nakliye Müfrezesi, Biga 600 yataklı Sihhiye Taburu, Lâpseki Ecza Deposu ${ }^{41}$

5 'inci Ordunun askeri nakliye hizmetlerine gelince Ordunun muharip birlikleri, Rumeli ve Anadolu yakalarında tertiplendiğinden ikmal yolları, hem Rumeli ya-

41 Türk Silahlı Kuvvetleri Tarihi Osmanl Devri Birinci Dünya Harbi’nde Türk Harbi V nci Cilt 3 ncü Kitap Çanakkale Cephesi Harekâtı (Haziran 1915-Ocak 1916), s. 525-526. 
kasında ve hem de Anadolu yakasında belirlenmiştir. 5'inci Ordunun 26 Mart 1915 tarihli konuş durumuna göre; Saros bölgesiyle Gelibolu Yarımadası'ndaki birlikler, ana ikmal yolu olarak İstanbul'dan Uzunköprü'ye kadar demir yolundan, Uzunköprü-Keşan-Bolayır-Gelibolu-Galata-Bigalı-Seddülbahir üzerinden geçen kara yolundan faydalanılmıştır. Ayrıca İstanbul'dan veya Marmara Denizi'nin kıyılarındaki iskelelerden yapılan deniz yoluyla Şarköy, Gelibolu, Galata, Ilgardere, Akbaş, Kilya, Maydos, Kilitbahir gibi liman ve iskelelerin üzerinden suyolu ulaştırması yapılmıştır. Şarköy'de bulunan 5'inci Menzil Kolları, söz konusu iskele veya istasyonlara getirilen ikmal maddelerini birliklerin civarında bulunan ileri menzil depolarına ulaștırmıștır. Anadolu yakasındaki birliklerin ana ikmal yolları, Biga-Bayramiç-Ezine-Erenköy-Çanakkale (Kale-i Sultaniye), Biga-Balcılar-Pirgos veya Işıklar, Biga-Çınardere-ÇardakLâpseki yolları olmuştur. Menzil kolları, Hamidiye, Enez ve Bayramiç bölgelerinde; birliklerin kollarıysa, Çanakkale ile Erenköy arasında askeri nakliyat faaliyetlerinde bulunmuşlardır. Ayrıca Karabiga, Çardak, Lâpseki ve Çanakkale liman veya iskeleleri üzerinden de suyolu ulaştırması yapılmıştır. Gerek menzil kollarının ve gerekse birlik kollarının görevlerini rahatlıkla yapabilmeleri için, indirme bindirme yerlerinde amele taburları bulundurulmuş; istihkâm inşaat taburları, bozulan yolların onarımını sağlamış veya altyapı tesisleri yaparak yolları takviye etmiştir. Bu hizmetler, birliklerin dağıtım merkezlerine kadar uzanmıştır. Nokta komutanlıkları tarafından yol güzergâhında aşhaneler tesis edilmiş, çayhaneler açılmış, kolların veya erlerin sıcak yemek yemeleri ve istirahatları sağlanmıştır ${ }^{42}$. Yaralı ve hastaların muharebe alanı gerisindeki sağlık teşekküllerine veya hastanelere nakilleri; yeterli hasta taşıma aracı olmadığından, hasta nakliye arabalarından veya erzak, cephane getiren nakliye kollarından istifade edilerek yapılmıștır ${ }^{43}$.

Marmara Denizi'nde yapılan suyolu ulaştırmasında Akbaş Limanı kullanılmaya gayret edilmiş, mümkün olduğu kadar büyük nakliye gemileri yerine denizaltı tehdidinden korunması maksadıyla askerî römorkörler yedeğinde mavnalar, Şireket-i Hayriye'ye ait vapurlar ile yapılmasına gayret edilmiştir. Az su çeken bu tekneler, torpido isabetinden kurtarılacakları gibi battıkları takdirde mühim bir kuvvetin kaybedilmemiş olacağı değerlendirilmiştir. Marmara Denizi'ndeki gidip gelmelerin kıyıya yakın yapılması emredilmiş ve böylece deniz ulaştırmasında kullanılan gemilerin dalmış durumda sığ sulara giremeyecek olan İngiliz ve Fransız denizaltı gemilerinin taarruzundan korunması hedeflenmiştir. Donanma Komutanlığı emrinde bulunan Muâvenet-i Milliyye ve Gayret-i Vataniyye muhripleri ve beş torpido bot 28 Nisan 1915 günü Çanakkale'ye gönderilmiş ve gemilere sınıflarına göre ayrı görevler tevdi edilmiştir. Muâvenet-i Milliyye sınıfı muhripler, Çanakkale'ye birlik ve malzeme gö-

42 Birinci Dünya Savaşıı'nda Çanakkale Cephesi Harekâtı (04 Haziran 1915-09 Ocak 1916), V. Cilt III. Kitap, s. 497-498; Arat, Çanakkale Savaşı'nın Lojistik Desteğinin..., s. 4-30.

43 Nurhan Aydın, "Çanakkale Savaşları’nda Sıhhiye ve Tahliye Hizmetleri” Atatürk Araștırma Merkezi Dergisi, Cilt: XXVI, Sayı: 77, (Temmuz 2010), http://www.atam.gov.tr/dergi/sayi-77/canakkalesavaslarinda-sihhiye-ve-tahliye-hizmetleri, (Erişim Tarihi: 25 Ağustos 2014). 
türen nakliye gemilerini yakından himaye etmekle görevlendirilmiştir ${ }^{44}$. Yine 1915 Eylül ayı başında yükünü boşaltmak üzere Akbaş Limanı'na gelen gemileri, denizaltıların torpidolarından korumak maksadıyla liman önüne bir torpido ağı tesis edilmiştir ${ }^{45}$. Fakat bütün gayretlere rağmen dört Fransız denizaltısı Marmara Denizi'ne girmeye teşebbüs etmiş, dördü de etkisiz hâle getirilmesine rağmen iki nakliye gemisi, beş buharlı tekne ve on dört yelkenli söz konusu deniz altılar tarafindan batırılmıştır ${ }^{46}$. Öte yandan Yavuz ve Midilli başta olmak üzere Türk savaş gemileri, bir Rus mayın gemisini batırmış, bir torpidobotu ağır hasara uğratmış, bir kömür gemisini 3 subayı, 72 personeli ile esir almıştır. Midilli gemisi ise Novorosisk limanında 50 petrol deposunu hasara uğratmış, 15 nakliye gemisini batırmıştır ${ }^{47}$. Öte yandan Çanakkale'de İngiliz ve Fransızların "Salib-i Ahmer vapurları ile seyyar hastaneleri; askeri nakliyat ve askeri maksatlar ile kullanılarak" harp esaslarına aykırı davranıldığına dair istihbarat raporları alınmıştır ${ }^{48}$.

Marmara deniz (suyolu) ulaştırmasının sağladığı kolaylıklardan önemli ölçüde faydalanılmıştır. Marmara Denizi'ne düşman denizaltılarının sızmış olması, alınan tedbirlerle bu hizmeti pek fazla aksatmamıştır. Bölgeler için başlıca ikmal noktaları yakın ve uygun yerlerde kurulmuştur. Arıburnu için ilk kez Eceabat - Kilye hattında dağıtma noktaları açılmış, bu iskelelerin düşman gemileri tarafından bombardıman edilmesi sonrası yerleri değiștirilmiş ve Akbaş (Bigalı) İskelesi'nden istifade edilmiştir. Ayrıca muharebelerin sıkışık dönemlerinde iş görmek üzere Kocadere köyü dolaylarında da ileri dağıtma noktaları kurulmuştur ${ }^{49}$. Akbaş (Bigalı) Limanı'nın yanı sıra Maydos (Eceabat) Limanı da deniz nakliyatı limanı olarak seçilmiştir. Hasta ve yaralı naklinde dört adet hastane gemisi (Gülcemal, Şirket-i Hayriye'nin 60, 61, 63 Nu.lı gemileri $)^{50}$ yanı sıra Akbaş ve Maydos Limanlarına yükünü boşaltan ve boş dönecek nakliye gemilerinden istifade edilmiştir ${ }^{51}$.

Marmara Denizi'ndeki düşman denizaltılarının gemilere saldırıya başlamalarından sonra vapurlarla sadece cephane ve asker taşınmasına karar verilmiştir. 10 Mayıs 1915 'te asker nakliyatı yapan Gülcemal Vapuru'nun torpillenip, yoluna devam edemeyecek kadar hasar görmesi, genel karargâhın aldığı önlem gereği denizden sadece

44 Figen Atabey, Çanakkale Savaşları’nın Deniz Cephesi, Ankara Üniversitesi Sosyal Bilimler Enstitüsü, Ankara, 2010, s. 218 (Yayınlanmamış Doktora Tezi).

45 Atabey, Çanakkale Savaşları'nın Deniz Cephesi, s. 223.

46 Atabey, Çanakkale Savaşlarinıın Deniz Cephesi, s. 241.

47 Atabey, Çanakkale Savaşlarinın Deniz Cephesi, s. 35.

48 BOA, HR.HMŞ.İ̧̧O., (Hariciye Nezareti İstişare Odası), 67/19, 20/Tş/1331 (2 Kasım 1915).

49 Birinci Dünya Savaşı'nda Çanakkale Cephesi (Amfibi Harekat), (V. Cilt, II. Kitap), s. 273.

50 Söz konusu Gülcemal, Şirket-i Hayriye'nin 60, 61, 63 Nu.lı gemileri Hilal-i Ahmer (Kızılay) işareti taşımalarına rağmen masrafları Erkan-ı Harbiye Umumi Riyaseti tarafından karşılanmıştır, (Ahmet Esenkaya, "Çanakkale Muharebelerinde Cephede ve Cephe Dışında Sağlık Hizmetleri”, Çanakkale Savaşları Türk Yıllığı, Çanakkale Onsekiz Mart Üniversitesi Atatürk ve Çanakkale Savaşları Araştırma Merkezi Yay., Yıl: 9, Sayı: 10-11, (Bahar-Güz 2011), 25-70, s. 41.

51 Nejat İnanır, Çanakkale Savaşları'nda Türk tarafının İdari ve Lojistik İkmali..., Silahlı Kuvvetler Akademisi, İstanbul, 2010, s. 4-29 (Yayınlanmamış Akademi Tezi). 
iâşe ikmâli ve hasta nakli yapılmasına karar verilmiştir. ${ }^{52}$

Menzil Komutanlığı emrinde bulunan askeri nakliye kollarının taşıma kapasiteleri araba veya hayvan mevcuduna bağlı olarak değişmekle birlikte, ortalama olarak şöyle hesaplanmıştır:

\begin{tabular}{|l|l|}
\hline Karayolu Nakliye Vasıtası & Taşıma Kapasitesi \\
\hline Bir mekkâre veya bir merkep kolu & 9 ton \\
\hline Bir kağnı kolu & 10 ton \\
\hline Bir deve kolu & 15 ton \\
\hline Bir at arabası kolu & 25 ton \\
\hline
\end{tabular}

Öküz arabalarından kurulu kollar, taşıdıkları ağırlıkların fazlalığından dolayı, ağır erzak kolu veya ağır cephane kolu olarak isimlendirilmiş; diğer cins arabalardan veya canlı nakil araçlarından oluşan kollara da hafif erzak kolu veya hafif cephane kolu adı verilmiştir. Kollar, hem yürüyüş hız ve kabiliyetinin korunması ve hem de arazinin göstereceği müşkülatın beraberce yenilmesi bakımından aynı cins araba veya hayvanlardan oluşturulmuştur. Nakliye kollarının ihtiyacını sağlamak ve gereğinde yardımlaşmayı temin etmek bakımından, birkaç nakliye kolu birleştirilerek katarlar teşkil edilmiş ve bu katarlar, muayyen merhaleler arasında görevlendirilmiştir. Bu suretle katarlar hâlinde düzenlenen 5 'inci Menzil Komutanlığına bağlı nakliye kolları, belirtilen varış ve dönüş noktaları arasında çalışmış; birliklerin erzak, cephane, odun, kömür, kereste gibi ihtiyaç maddelerini taşımışlardır. Nakliyatta kullanılacak çuvalların ikmali için yurt için satın alma ve imal etme yoluna gidilmiştir ${ }^{53}$. 5 'inci Ordu Menzil Kolları, 5'inci Ordu mevcudunun artması üzerine, zaman zaman 2'nci Ordu Menzil Kollarıyla takviye edilmiş ve hatta çok sıkışık zamanlarda, muharebe gruplarının kollarından da faydalanılmıștır. Menzil kollarının yanı sıra 5 'inci Ordunun muharip birliklerinin de nakliye kolları ikmal noktasından birliğe kadar askeri nakliye hizmetleri yapmışlardır. Bu kollar, muharebe alanının hemen gerisinde kurulmuş olan menzil ambarlarındaki ihtiyaç maddelerini muharebe gruplarının ambarlarına taşımakta ve gibi ihtiyaç hasıl olduğu zamanlarda menzil kollarını takviyede kullanılmıştır. 5'inci Ordu Menzil kollarıyla bu kolların çalıştığı bölgeler ve diğer menzil teşkillerinin 30 Eylül 1915'deki durumu Ek-6'da sunulmuştur ${ }^{54}$. 5'inci Ordu Menzil teşkilatı Eylül 1915 başlarında en geniş ve en ileri düzeye ulaşmıştır ${ }^{55}$.

5 'inci Ordu bölgesindeki birliklerin askeri nakliye kolları aşağıdaki şekilde teşkilatlanmıştır: ${ }^{56}$

52 Erdemir, Çanakkale Savaşı Siyasi Askeri ve Sosyal Yönleri, s. 237.

53 BOA, DH.ŞFR. (Dahiliye Nezareti Şifre Kalemi) 54/341, 28/N /1333 (Hicrî), (9 Ağustos 1915).

54. Türk Silahlı Kuvvetleri Tarihi Osmanlı Devri Birinci Dünya Harbi’nde Türk Harbi V nci Cilt 3 ncü Kitap Çanakkale Cephesi Harekâtı (Haziran 1915-Ocak 1916), s. Kroki: 59.

55 Gürsel Göncü ve Şahin Aldoğan, Çanakkale Savaşı, Siperin Ardı Vatan, MB Yay., İstanbul, 2006, s. 136.

56 Birinci Dünya Savaşı'nda Çanakkale Cephesi Harekâtı (04 Haziran 1915-09 Ocak 1916), V. Cilt III. Kitap, s. 500. 


\begin{tabular}{|c|c|c|c|c|}
\hline Birliği & Kolun Cinsi & Hafif Kollar & Ağır Kollar & Açıklama \\
\hline \multirow[b]{2}{*}{$\begin{array}{l}\text { 3’üncü } \\
\text { Kor. }\end{array}$} & Erzak Kolları & $\begin{array}{l}\text { 4 adet çift atlı araba } \\
\text { kolu }\end{array}$ & $\begin{array}{l}7 \text { adet öküz } \\
\text { araba kolu }\end{array}$ & $\begin{array}{l}\text { Erzak kollarının } \\
\text { tümü birden } 230 \text { ton } \\
\text { kapasitededir. }\end{array}$ \\
\hline & $\begin{array}{l}\text { Cephane } \\
\text { Kolları }\end{array}$ & $\begin{array}{l}5 \text { adet piyade } \\
\text { Cephane kolu (Hepsi } \\
80 \text { ton kapasitededir.) }\end{array}$ & $\begin{array}{l}4 \text { adet dağ } \\
\text { cephane kolu } 7 \\
\text { adet sahra top, } \\
\text { cephane kolu } \\
\end{array}$ & $\begin{array}{l}\text { Hepsi birden } 211 \text { ton } \\
\text { kapasitededir. }\end{array}$ \\
\hline \multirow[b]{2}{*}{$\begin{array}{l}16 \text { 'nc1 } \\
\text { Kor. }\end{array}$} & Erzak Kolları & $\begin{array}{l}6 \text { adet çift atlı araba } \\
\text { kolu }\end{array}$ & $\begin{array}{l}4 \text { adet öküz } \\
\text { araba kolu }\end{array}$ & $\begin{array}{l}\text { Erzak kolları, } 166 \text { Ton } \\
\text { kapasitededir. }\end{array}$ \\
\hline & $\begin{array}{l}\text { Cephane } \\
\text { Kolları }\end{array}$ & $\begin{array}{l}4 \text { adet piyade } \\
\text { Cephane kolu (Hepsi } \\
51 \text { ton kapasitededir.) }\end{array}$ & $\begin{array}{l}2 \text { adet dağ } \\
\text { cephane kolu } \\
4 \text { adet sahra } \\
\text { cephane kolu } \\
\end{array}$ & $\begin{array}{l}\text { Hepsi birden } 70 \text { ton } \\
\text { kapasitededir. }\end{array}$ \\
\hline \multirow[b]{2}{*}{$\begin{array}{l}15 \text { 'inci } \\
\text { Kor. }\end{array}$} & Erzak Kolları & $\begin{array}{l}5 \text { adet çift atlı araba } \\
\text { kolu }\end{array}$ & $\begin{array}{l}5 \text { adet öküz } \\
\text { araba kolu }\end{array}$ & $\begin{array}{l}\text { Hepsi birden } 222 \text { ton } \\
\text { kapasitededir. }\end{array}$ \\
\hline & $\begin{array}{l}\text { Cephane } \\
\text { Kolları }\end{array}$ & $\begin{array}{l}4 \text { adet piyade } \\
\text { Cephane kolu (Hepsi } \\
53 \text { ton kapasitededir.) }\end{array}$ & \begin{tabular}{|l|}
2 adet dağ \\
cephane kolu \\
4 adet sahra \\
cephane kolu \\
\end{tabular} & $\begin{array}{l}\text { Hepsi birden } 70 \text { ton } \\
\text { kapasitededir. }\end{array}$ \\
\hline \multirow[b]{2}{*}{$\begin{array}{l}\text { 15’inci } \\
\text { Tüm. }\end{array}$} & Erzak Kolları & $\begin{array}{l}2 \text { adet çift atlı araba } \\
\text { kolu }\end{array}$ & \begin{tabular}{|l|}
$\begin{array}{l}2 \text { adet öküz } \\
\text { araba kolu }\end{array}$ \\
\end{tabular} & $\begin{array}{l}\text { Hepsi birden } 82 \text { ton } \\
\text { kapasitededir. }\end{array}$ \\
\hline & $\begin{array}{l}\text { Cephane } \\
\text { Kolları }\end{array}$ & $\begin{array}{l}2 \text { adet piyade } \\
\text { Cephane kolu (Hepsi } \\
53 \text { ton kapasitededir.) }\end{array}$ & \begin{tabular}{|l|}
1 adet dağ \\
cephane kolu \\
1 adet sahra \\
cephane kolu \\
\end{tabular} & $\begin{array}{l}\text { Hepsi birden } 23 \text { ton } \\
\text { kapasitededir. }\end{array}$ \\
\hline \multirow{2}{*}{$\begin{array}{l}\text { 12'nci } \\
\text { Tüm. }\end{array}$} & Erzak Kolları & $\begin{array}{l}2 \text { adet çift atlı araba } \\
\text { kolu }\end{array}$ & $\begin{array}{l}\begin{array}{l}\text { adet öküz } \\
\text { araba kolu }\end{array} \\
\end{array}$ & $\begin{array}{l}\text { Hepsi birden } 82 \text { ton } \\
\text { kapasitededir. }\end{array}$ \\
\hline & $\begin{array}{l}\text { Cephane } \\
\text { Kolları }\end{array}$ & $\begin{array}{l}2 \text { adet piyade } \\
\text { Cephane kolu (17 ton } \\
\text { kapasitededir.) }\end{array}$ & $\begin{array}{l}3 \text { adet sahra } \\
\text { cephane kolu }\end{array}$ & $\begin{array}{l}\text { Hepsi birden } 30 \text { ton } \\
\text { kapasitededir. }\end{array}$ \\
\hline \multirow{2}{*}{$\begin{array}{l}\text { 1'inci } \\
\text { Tüm. }\end{array}$} & Erzak Kolları & $\begin{array}{l}2 \text { adet çift atlı araba } \\
\text { kolu }\end{array}$ & $\begin{array}{l}3 \text { adet öküz } \\
\text { araba kolu }\end{array}$ & $\begin{array}{l}\text { Hepsi birden } 100 \text { ton } \\
\text { kapasitededir. }\end{array}$ \\
\hline & $\begin{array}{l}\text { Cephane } \\
\text { Kolları }\end{array}$ & $\begin{array}{l}3 \text { adet piyade } \\
\text { Cephane kolu ( } 30 \text { ton } \\
\text { kapasitededir.) }\end{array}$ & $\begin{array}{l}2 \text { adet obüs } \\
\text { cephane kolu }\end{array}$ & $\begin{array}{l}\text { Hepsi birden } 40 \text { ton } \\
\text { kapasitededir. }\end{array}$ \\
\hline \multirow{2}{*}{$\begin{array}{l}\text { 2'nci } \\
\text { Tüm. }\end{array}$} & Erzak Kolları & $\begin{array}{l}2 \text { adet çift atlı araba } \\
\text { kolu }\end{array}$ & \begin{tabular}{|l}
$\begin{array}{l}2 \text { adet öküz } \\
\text { araba kolu }\end{array}$ \\
\end{tabular} & $\begin{array}{l}\text { Hepsi birden } 82 \text { ton } \\
\text { kapasitededir. }\end{array}$ \\
\hline & $\begin{array}{l}\text { Cephane } \\
\text { Kolları }\end{array}$ & $\begin{array}{l}2 \text { adet piyade } \\
\text { Cephane kolu ( } 30 \text { ton } \\
\text { kapasitededir.) }\end{array}$ & $\begin{array}{l}2 \text { adet sahra } \\
\text { cephane kolu }\end{array}$ & $\begin{array}{l}\text { Hepsi birden } 20 \text { ton } \\
\text { kapasitededir. }\end{array}$ \\
\hline
\end{tabular}

Harekâtın daha etkili olarak yürütülebilmesini sağlamak maksadıyla Çanakkale harekât bölgesindeki birliklerin Güney Grubu, Kuzey Grubu ve Saros Grubu olarak 
ayrılmalarına bağlı olarak bu grup komutanlıklarının nakliye kolları oluşturulmuş; 5 'inci Menzil Komutanlığınca muharebe sahasının hemen gerisinde açılan menzil ambarlarıyla dağıtım yerleri arasındaki nakliyat, bu grupların nakliye kolları vasıtasıyla yürütülmüștür ${ }^{57}$.

5 'inci Ordunun Grup Komutanlıklarının askeri nakliye kollarının taşıma kapasitesi ise aşağıdaki şekildedir ${ }^{58}$ :

\begin{tabular}{|l|l|l|}
\hline Grubun Adı & Erzak Kolları ve Kapasitesi & Cephane Kolları ve Kapasitesi \\
\hline Saros Grubu & 4 ağır erzak kolu (96 ton) & 5 cephane kolu (87 ton) \\
\hline Kuzey Grubu & $\begin{array}{l}7 \text { hafif erzak kolu } \\
10 \text { ağır erzak kolu (306 ton) }\end{array}$ & 19 cephane kolu (274 ton) \\
\hline Güney Grubu & $\begin{array}{l}8 \text { hafif erzak kolu } \\
8 \text { ağır erzak kolu (314 ton) }\end{array}$ & 9 cephane kolu (104 ton) \\
\hline Toplam Kapasite & 37 kolun taşıdığ yük (716 ton) & 33 kolun taşıdığ yük (465 ton) \\
\hline
\end{tabular}

Askeri nakliye ve diğer menzil hizmetlerini karşılamak maksadıyla 30 Ocak 1912, 18 Ağustos 1912 ve 27 Temmuz 1914 tarihli kanunların yanı sıra Tekâlif-i Harbiye esaslarına açıklık getirmek maksadıyla 26 Kasım 1916'da Meclis-i Vükela kararı çıkarılmıștır. Söz konusu karar gereğince el konulan mal ve nakliye hizmetleri karşllığında karşıllğı harp sonunda ödenmek üzere; Tekâlif-i Harbiye Komisyonlarınca mazbata tanzim edilmesine, hatta zor durumda bulunan mülteci halkın ihtiyaçları için bedellerin harp öncesi ödenmesine karar verilmiştir. Düşman devletlerin halkından olanların çiftliklerinin ürünlerine ve azınlıkların da mal ve mülklerine de Tekâlif-i Harbiye yoluyla el konulmasına karar verilmiști ${ }^{59}$. Fakat bu durum tepkilere neden olmuş, "Askeri nakliyat mükellefiyetinin ecnebi tebaaya tatbikinin ikamet mukavelesine aykırı olduğuna" dair İngiliz, Fransız ve İtalyan temsilcilikleri müşterek olarak Osmanlı Hükümetine nota vermiștir ${ }^{60}$. Tekâlif-i Harbiye Komisyonlarınca tanzim edilen mazbataların karşıllklarının "hiçbir zaman ödenmeyeceği" fikri olumsuz bir propaganda aracı olarak yayılmış, hatta bazıları bu mazbataları imha etmiştir. Bunun üzerine halkın mağdur olmaması için defterlere şerh düşülerek mazbataların yeniden

57 Birinci Dünya Savaşı’nda Çanakkale Cephesi Harekâtı (04 Haziran 1915-09 Ocak 1916), V. Cilt III. Kitap, s. 500.

58 Birinci Dünya Savaşı’nda Çanakkale Cephesi Harekâtı (04 Haziran 1915-09 Ocak 1916), V. Cilt III. Kitap, s. 501.

59 BOA, BEO (Babıali Evrak Odası), 4408/ 330582, 10/C/1334 (Hicrî) (14 Nisan 1916); BOA, MV., (Meclis-i Vükela Mazbataları), 203/39, 19/Za/1334 (Hicrî), (17 Eylül 1916).

60 BOA, HR.IM.. (Hariciye Nezareti İstanbul Murahhaslığı), 246/119, 19/Ca/1334 (Hicrî). (24 Mart 1916). 
tanzim edilmesine karar verilmiştir ${ }^{61}$. Tekâlif-i Harbiye usulüyle el konulan nakliye hayvanlarından vergi alınmamasına karar verilmiștir ${ }^{62}$.

Tekâlif-i Harbiye Komisyonlarınca verilen mazbataların karşıllı̆ı halk için bir geçim kaynağı haline gelmiştir. Bu mazbatalar bazen nakit para karşılığı satılmış, bazen de borçlanmak için teminat yerine kullanılmıştır. Bu tür suiistimallerin önüne geçmek maksadıyla tanzim edilen bir emirname ile mazbataların ticari maksatla kullanılması yasaklanmıștır. Askeri Nakliye hizmetleri için bazı bölge halkının kalkındırılması için teşvik olarak da kullanılmıştır. Bunlardan Lâpseki'deki Çanakkaleli Balkan mültecileri, "verdikleri vesait-i nakliye bedellerinin ödenmemesi karşısında maişetlerini verdikleri hayvanlarla karşıladıklarından şu an sefalet içinde bulunduklarına dair" durumlarını telgraf ile şikâyet etmişlerdir ${ }^{63}$.

\section{Sonuç}

5 'inci Ordunun lojistik ve idari hizmetleri (askeri nakliye hizmetleri dâhil) büyük ölçüde 5 'inci Ordu Menzil Müfettişliği tarafından yürütülmüştür. Ordunun menzil sınırları Bandırma - Tekirdağ hattına kadar uzanmıștır. Bu bakımdan Ordu Menzil Müfettişliği tarafından, Marmara havzasının hemen her bölgesinde teşkilatlanarak yurt içi kaynakların en zengin kısımlarından istifade edilmiştir. Çanakkale Cephesi'nin en sıkışık ve bunalımlı günlerinde dahi ikmal işlerinden önemli bir şikâyet duyulmamıştır. İtilaf devletleri ordusu ile mukayese edildiğinde Türk Ordusunun çok konforlu şartlarda muharebe ettiğini söylemek mümkün olmasa da birçok kaynaktan mahrum edilmediği belirtilebilir.

Öte yandan dönemin basın-yayın organlarına göre; Tekâlif-i Harbiye uygulamaları kıtlığa, iaşe problemine, enflasyona ve karaborsacılığa sebebiyet vermiştir ${ }^{64}$.

Cephedeki muharebenin Türk Ordusu lehine başarı ile sonuçlanması sonrası 5’inci Ordu Komutanlığı Gelibolu bölgesinden alınarak yerine "Çanakkale Grubu Menzili" kurulmuştur ${ }^{65}$. Çanakkale cephesinde galibiyet sonrası Balkan Harbi mağlubiyetinin verdiği moral çöküntüsü Türk Ordusu'nun üzerinden atılmıştır. Beşinci Ordu Menzil Müfettişliği tarafından yaptırılan bir abide ${ }^{66}$ ile kazanılan zaferin ileriki kuşaklara aktarılması hedeflenmiştir.

61 BOA, DH.UMVM, (Dahiliye Nezareti Umur-u Mahalliye ve Vilayat Müdürlüğü), 123/120, 05/L /1333 (Hicrî) (16 Ağustos 1915).

62 BOA, DH.EUM.MEM. (Dahiliye Nezareti Memurin Kalemi), 72/4, 12/S /1334 (Hicrî), (20 Aralık 1915).

63 BOA, DH.I..UM.EK. (Dahiliye Nezareti İdare-i Umumiye Ekleri), 34/16, 19/Ş /1335 (Hicrî).

64 Sabah Gazetesi, 27 Temmuz 1330 (9 Ağustos 1914), s. 3.

65 BOA,DH.EUM.,2.Şube, 17/16, 20/Ra/1334 (Hicrî), (26 Ocak 1916).

66 BOA, DH.I..UM.EK. 24/50, 01/S /1335 (Hicrî), (27 Kasım 1916). 


\section{KAYNAKÇA}

\section{Arşiv Belgeleri}

Başbakanlık Osmanlı Arşivi

\section{Kitaplar}

Arat, İrfan, Çanakkale Savaşı̇nın Lojistik Desteğinin İncelenmesi ve Savaşın sonucuna Etkilerinin Değerlendirilmesi, Harp Akademileri Komutanlığı, İstanbul, 2008, (Kara Harp Akademisi Öğrenci Subay Tezi).

Atabey, Figen, Çanakkale Savaşları’nın Deniz Cephesi, Ankara Üniversitesi Sosyal Bilimler Enstitüsü, Ankara, 2010, (Yayınlanmamış Doktora Tezi).

Beşikçi, Mehmet, Between Voluntarism And Resistance: The Ottoman Mobilization Of Manpower In The First World War, Boğaziçi Üniversitesi, İstanbul, 2009, (Yayınmamış Doktora Tezi).

Birinci Dünya Harbi’nde Türk Harbi V nci Cilt Çanakkale Cephesi Harekâtı 1 nci Kitap (Haziran 1914-25 Nisan 1915), Genelkurmay Başkanlığı, ATASE Yay., Ankara, 1993.

Birinci Dünya Savaşı’nda Çanakkale Cephesi Harekâtı (Haziran 1914-25 Nisan 1915), V. Cilt 1. Kitap, Genelkurmay Personel Başkanlığı ATASE Daire Başkanlığı Yay., Ankara, 2012.

Birinci Dünya Savaşı'nda Çanakkale Cephesi (Amfibi Harekat), (V. Cilt, II. Kitap), Genelkurmay Personel Başkanlığı ATASE Daire Başkanlığı Yay., Ankara, 2012.

Birinci Dünya Savaşı'nda Çanakkale Cephesi Harekâtı (04 Haziran 1915-09 Ocak 1916), V. Cilt III. Kitap, Genelkurmay Personel Başkanlığı ATASE Daire Başkanlığı Yay., Ankara, 2012.

Erickson, Erdward J., Dünya Savaşı Tarihi, I. Dünya Savaşı'nda Osmanlı 1914-1918, Cilt: IV, (Çev.: Sare Levin Atalay), Timaş Yay., İstanbul, 2011.

Erdemir, Lokman, Çanakkale Savaşı Siyasi Askeri ve Sosyal Yönleri, Gökkubbe Yay., İstanbul, 2009.

Göncü, Gürsel ve ALDOĞAN, Şahin, Çanakkale Savaşı, Siperin Ardı Vatan, MB Yay., İstanbul, 2006.

Görgülü, İsmet, On Yıllık Harbin Kadrosu (1912-1922), TTK Yay., Ankara, 1993.

İnanır, Nejat, Çanakkale Savaşları’nda Türk tarafının İdari ve Lojistik İkmali..., Silahlı Kuvvetler Akademisi, İstanbul, 2010, (Yayınlanmamış Akademi Tezi).

Keskin, Özgür, Çanakkale Muharebeleri'nde Türk Ordusunun Lojistik Faaliyetleri, Kara Harp Okulu Savunma Bilimleri Enstitüsü, Ankara, 2007, (Yayınlanmamış Yüksek Lisans Tezi).

Örenç, Ali Fuat, Yakınçağ Tarihi (1789-1918), Ati Yay., İstanbul, 2012.

Özçelik, Mücahit, Türk Basını'nda Osmanlı Devleri’nin I. Dünya Savaşı’na Giriş Süreci, Gazi Üniversitesi Sosyal Bilimler Enstitüsü, Ankara, 2006, (Yayınlanmamış Yüksek Lisans Tezi).

Ruşen Eşref, Hamdullah Suphi vd., Çanakkale, Savaşanlar Anlatıyor, Örgün Yay., İstanbul, 2006. 
Tezcan, Cezmi, Tekâlif-i Harbiye ve Tekâlif-i Milliye Örneklerinde Savaş Dönemleri Mâli Politikaları, Ankara Üniversitesi Türk İnkılâp Tarihi Enstitüsü, Ankara, 2005, (Yayımlanmamış Doktora Tezi).

Toker, Hülya, Çanakkale Muharebelerine Katılan Komutanların Biyografileri (Belge ve Fotoğraflarla), Genelkurmay Askerî Tarih ve Stratejik Etüt (ATASE) Daire Başkanlığı Yay., Ankara, 2014.

Türk Silahlı Kuvvetleri Tarihi Osmanlı Devri Birinci Dünya Harbi’nde Türk Harbi V nci Cilt 3 ncü Kitap Çanakkale Cephesi Harekâtı (Haziran 1915-Ocak 1916), Genelkurmay Başkanlığı ATASE Yay., Ankara, 1980.

Türkmen, Zekeriya, Çanakkale 1915 Türk Ordusunun Kara ve Hava Harekatı, Berikan Yay., Ankara, 2010.

\section{Makaleler}

Aydın, Nurhan, “Çanakkale Savaşları’nda Sıhhiye ve Tahliye Hizmetleri” Atatürk Araştırma Merkezi Dergisi, Cilt: XXVI, Sayı: 77 (Temmuz 2010), http://www.atam.gov.tr/dergi/ sayi-77/canakkale-savaslarinda-sihhiye-ve-tahliye-hizmetleri, (Erişim Tarihi: 25 Ağustos 2014).

Erat, Muhammet, “Çanakkale Muharebelerinde Türk Ordusunun İaşe Problemi”, Çanakkale Araştırmaları Türk Yıllı̆̆ı, Çanakkale Onsekiz Mart Üniversitesi Atatürk ve Çanakkale Savaşları Araştırma Merkezi Yay., Sayı: 1, (Mart 2003), 114-133.

Esenkaya, Ahmet, "Çanakkale Muharebelerinde Cephede ve Cephe Dışında Sağlık Hizmetleri”, Çanakkale Savaşları Türk Yıllĭ̆l, Çanakkale Onsekiz Mart Üniversitesi Atatürk ve Çanakkale Savaşları Araştırma Merkezi Yay., Yıl: 9, Sayı: 10-11, (Bahar-Güz 2011), 25-70. 


\section{Ekler}

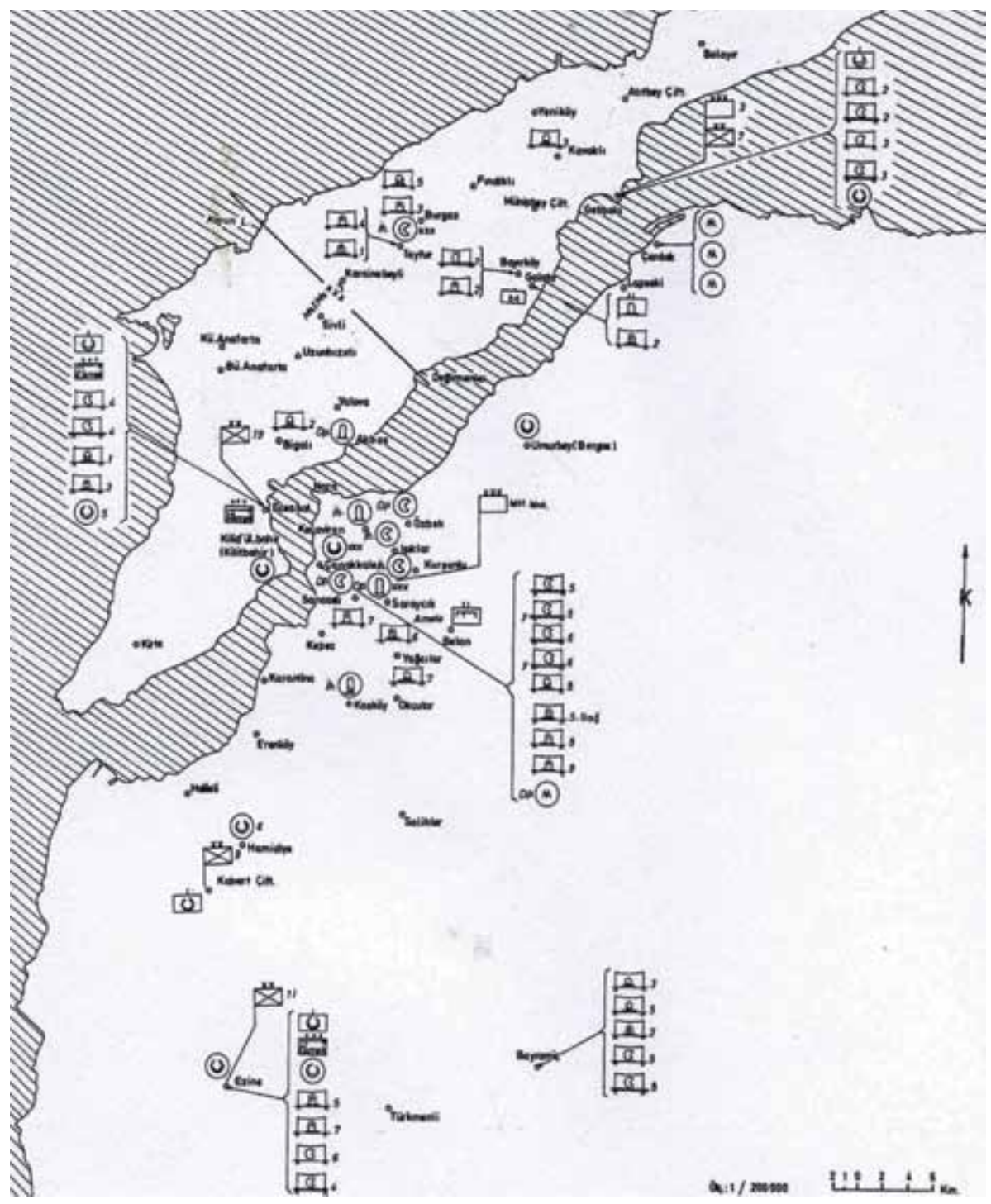

EK-1 Çanakkale Cephesi Menzil Teşkilatının Konuş Yerleri (5’inci Or. Kuruluşu Öncesi-Mart 1915)

Birinci Dünya Harbi’nde Türk Harbi Vnci Cilt Çanakkale Cephesi Harekâtı 1 nci Kitap (Haziran 1914-25 Nisan 1915), Genelkurmay Başkanlığı, ATASE Yay., Ankara, 1993, s. Kroki:18. 


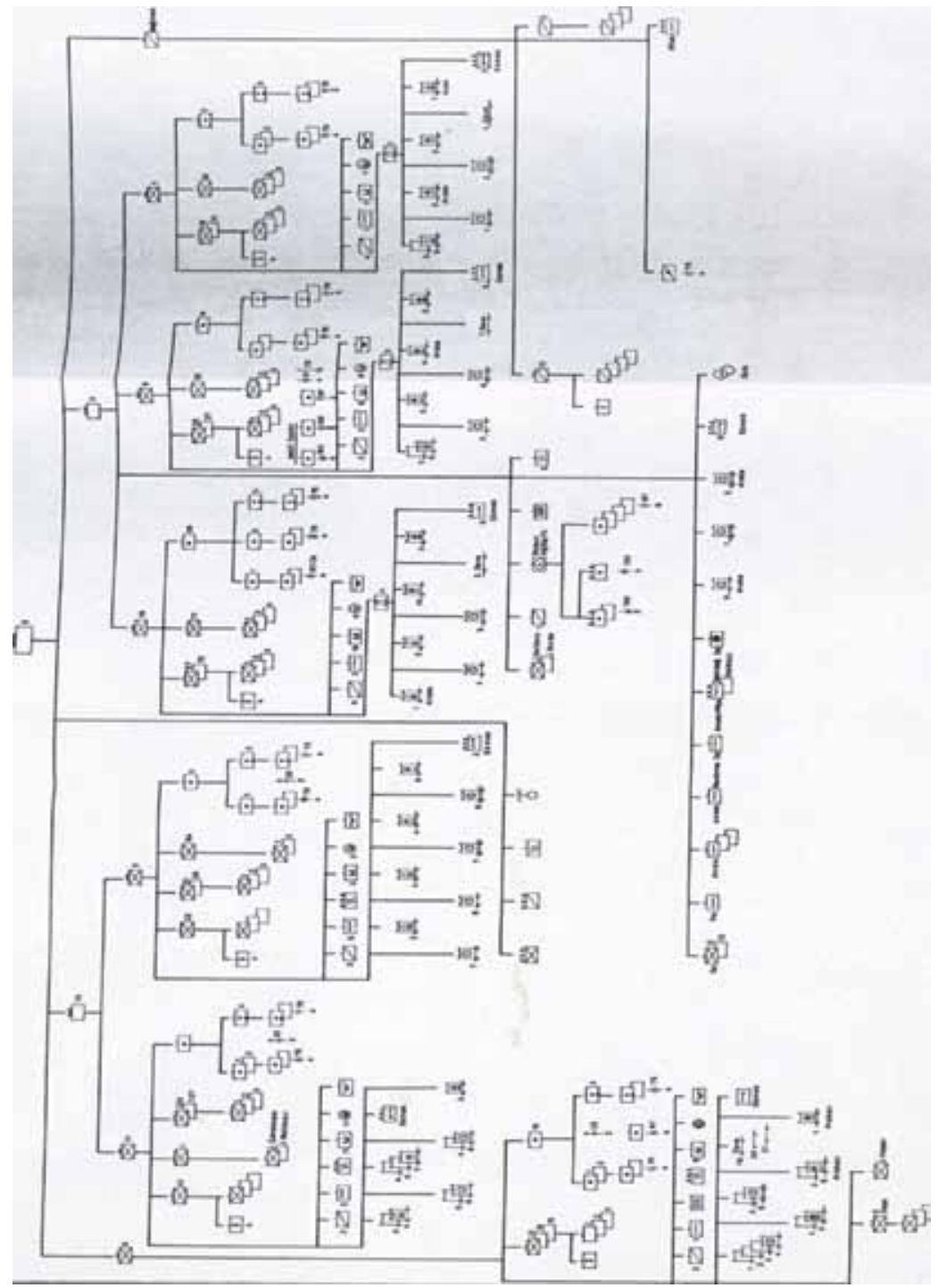

EK-2 Çanakkale Cephesinde 5 'inci Ordu Komutanlığı Kuruluşu (19 Nisan 1915)

Birinci Dünya Harbi’nde Türk Harbi Vnci Cilt Çanakkale Cephesi Harekâtı 1 nci Kitap (Haziran 1914-25 Nisan 1915), Genelkurmay Başkanlığı, ATASE Yay., Ankara, 1993, s. Kuruluş:12. 


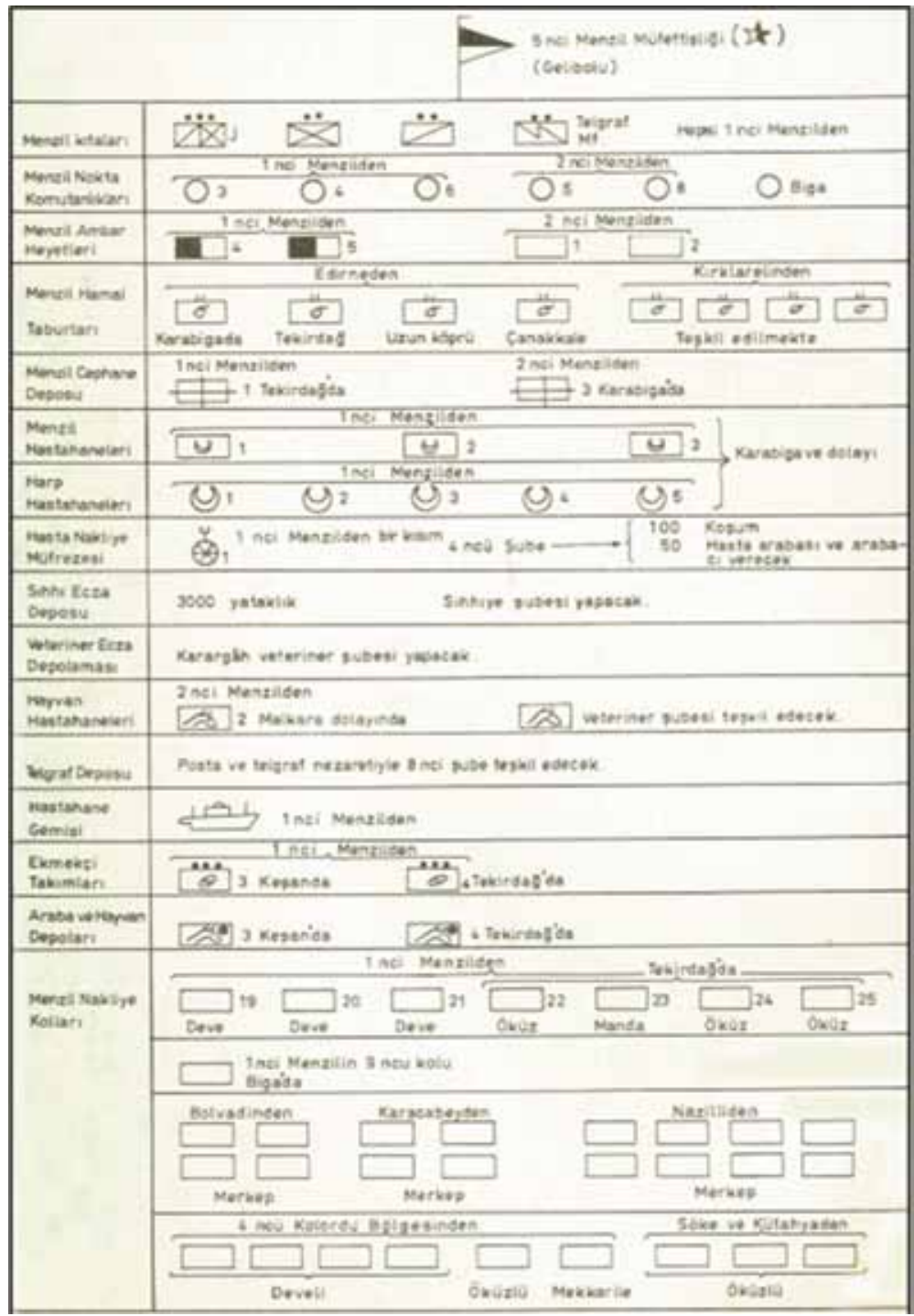

EK-3 Çanakkale Cephesinde 5’inci Ordu Menzil Müfettişliği Kuruluşu (27 Mart 1915)

Türk Silahlı Kuvvetleri Tarihi Osmanlı Devri Birinci Dünya Harbi’nde Türk Harbi V nci Cilt 3 ncü Kitap Çanakkale Cephesi Harekâtı (Haziran 1915-Ocak 1916), Genelkurmay Başkanlığı ATASE Yay., Ankara, 1980, s. Kuruluş:15. 


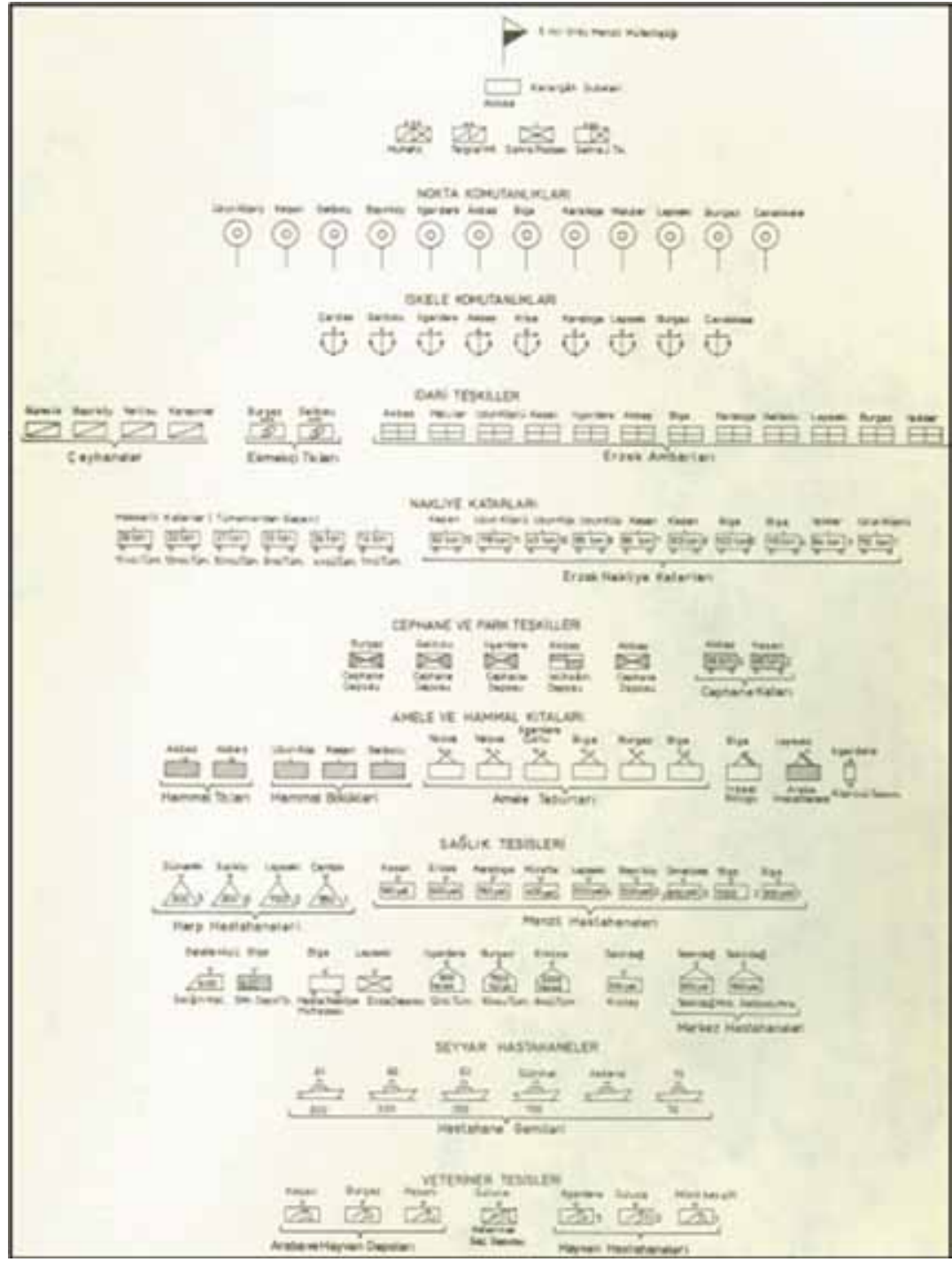

EK-4 Çanakkale Cephesinde 5’inci Ordu Menzil Müfettişliği Daha Sonraki Kuruluşu (Eylül 1915)

Türk Silahlı Kuvvetleri Tarihi Osmanlı Devri Birinci Dünya Harbi’nde Türk Harbi V nci Cilt 3 ncü Kitap Çanakkale Cephesi Harekâtı (Haziran 1915-Ocak 1916), Genelkurmay Başkanlığı ATASE Yay., Ankara, 1980, s. Kuruluş:16. 


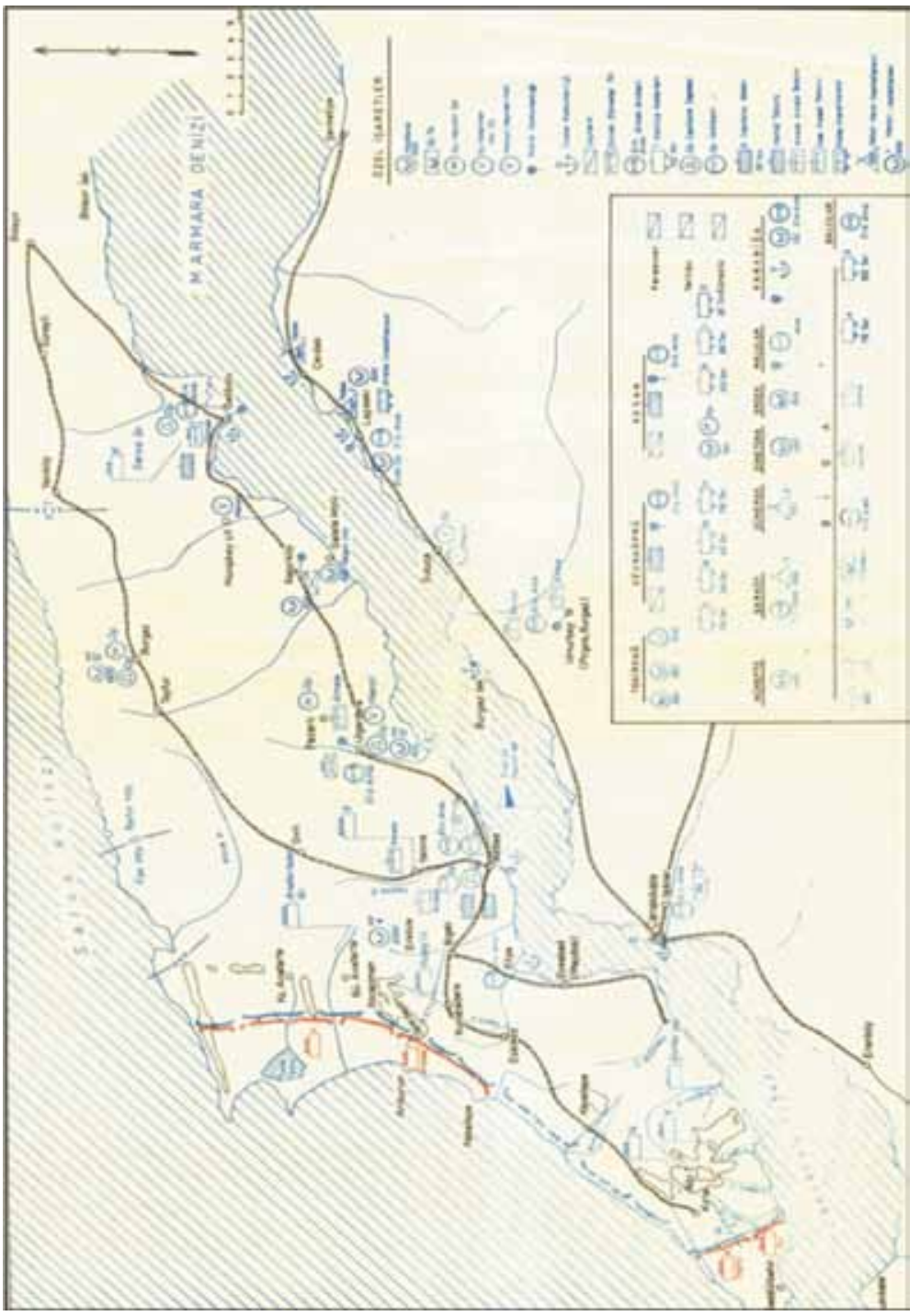

EK-5 Çanakkale Cephesinde 5’inci Ordu Bölgesindeki Menzil Teşkilatı Konuş Yerleri

Türk Silahlı Kuvvetleri Tarihi Osmanlı Devri Birinci Dünya Harbi’nde Türk Harbi Vnci Cilt 3 ncü Kitap Çanakkale Cephesi Harekâtı (Haziran 1915-Ocak 1916), Genelkurmay Başkanlığı ATASE Yay., Ankara, 1980, s. Kroki: 60. 


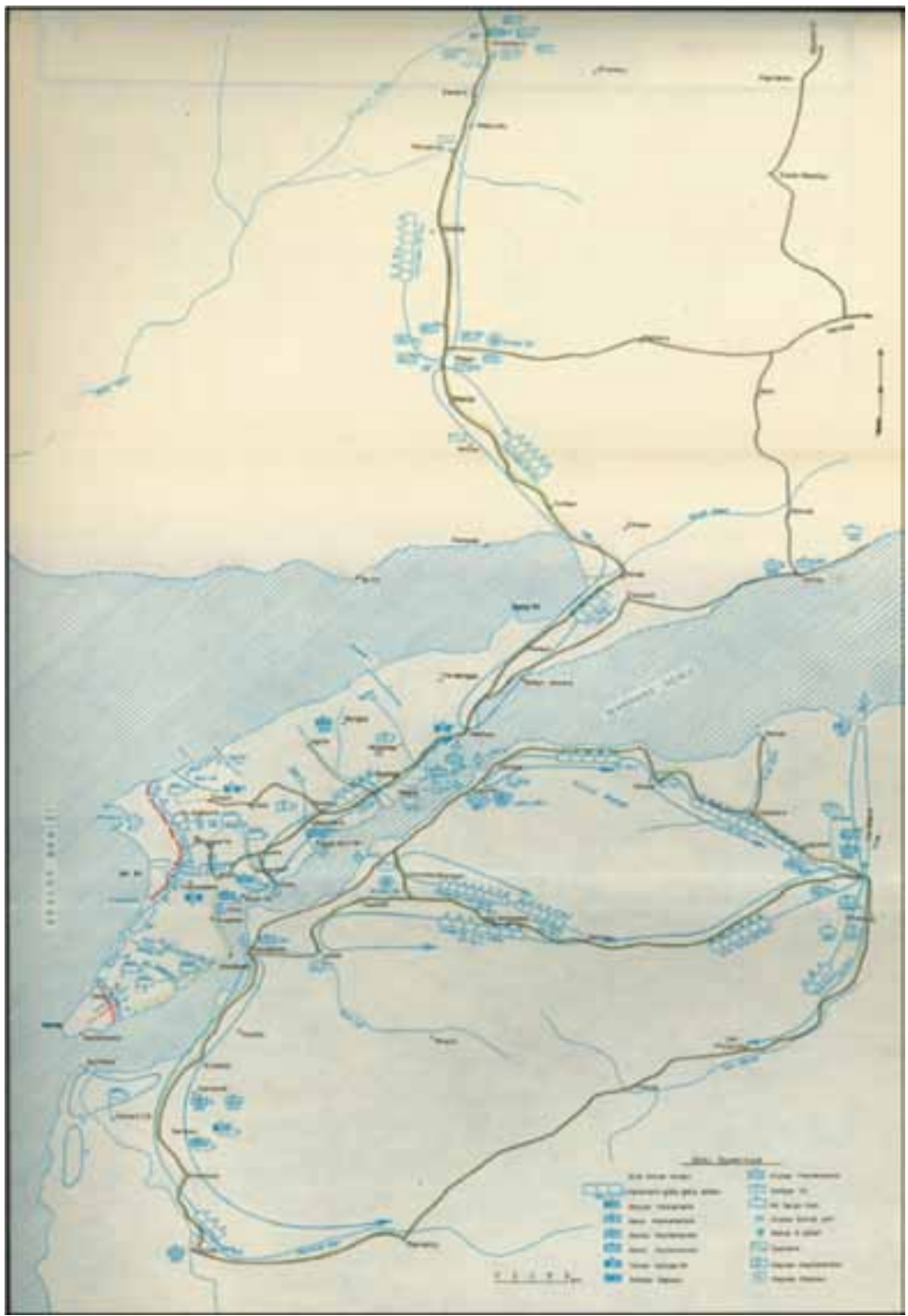

EK-6 Çanakkale Cephesinde 5’inci Ordu Menzil Kollarıyla Bu Kolların Çalıştığı Bölgeler ve Diğer Menzil Teşkilleri (30 Eylül 1915)

Türk Silahlı Kuvvetleri Tarihi Osmanlı Devri Birinci Dünya Harbi’nde Türk Harbi V nci Cilt 3 ncü Kitap Çanakkale Cephesi Harekâtı (Haziran 1915-Ocak 1916), Genelkurmay Başkanlığı ATASE Yay., Ankara, 1980, s. Kroki: 59. 
